AperTO - Archivio Istituzionale Open Access dell'Università di Torino

\title{
Click chemistry under microwave or ultrasound irradiation.
}

\section{This is the author's manuscript}

Original Citation:

\section{Availability:}

This version is available http://hdl.handle.net/2318/88545

since 2016-01-26T16:32:44Z

Terms of use:

Open Access

Anyone can freely access the full text of works made available as "Open Access". Works made available under a Creative Commons license can be used according to the terms and conditions of said license. Use of all other works requires consent of the right holder (author or publisher) if not exempted from copyright protection by the applicable law. 


\section{(2) \\ UNIVERSITÀ DEGLI STUDI DI TORINO}

This is an author version of the contribution published on:

[Current Organic Chemistry, 12 (2), 2011,

DOI: $10.2174 / 138527211793979826$

Alessandro Barge, Silvia Tagliapietra, Arianna Binello, Giancarlo Cravotto

12, BENTHAM SCIENCE PUBL LTD, 2011,189-203]

The definitive version is available at:

[http://www.ingentaconnect.com/content/ben/coc/2011/00000015/00000002/ar t00005] 


\title{
Click Chemistry Under Microwave or Ultrasound Irradiation
}

\author{
Alessandro Barge, Silvia Tagliapietra, Arianna Binello and Giancarlo Cravotto* \\ Dipartimento di Scienza e Tecnologia del Farmaco, Università di Torino, Via Giuria 9, 10125- Torino, Italy
}

\begin{abstract}
The copper-catalyzed azide-alkyne cycloaddition (CuAAC) is generally recognized as the most striking example of "click reaction". CuAAC fit so well into Sharpless' definition that it became almost synonymous with "click chemistry" itself. The most common catalyst systems employ $\mathrm{Cu}(\mathrm{II})$ salt in the presence of a reducing agent (i.e. sodium ascorbate) to generate the required $\mathrm{Cu}(\mathrm{I})$ catalyst in situ or as an alternative the comproportionation of $\mathrm{Cu}(\mathrm{II}) / \mathrm{Cu}(0)$ species. Although, $\mathrm{Cu}(\mathrm{I})$ catalyzes the reaction with a rate enhancement of $\approx 10^{7}$ even in the absence of ligands and provides a clean and selective conversion to the 1,4-substituted triazoles, some bulky and scantily reactive substrates still require long reaction times and often few side products are formed. Outstanding results have been achieved by performing CuAAC under microwave (MW) irradiation. Several authors described excellent yields, high purity and short reaction times. In few cases also power ultrasound (US) accelerated the reaction, especially when heterogeneous catalysts or metallic copper are employed. The aim of this review is to summarize and highlight the huge advantages offered by $\mathrm{MW}$ - and US-promoted $\mathrm{CuAAC}$. In the growing scenario of innovative synthetic strategies, we intend to emphasize the complementary role played by these nonconventional energy sources and click chemistry to achieve process intensification in organic synthesis.
\end{abstract}

Keywords: Click chemistry, microwave, ultrasound, organic synthesis, green chemistry.

\section{INTRODUCTION}

Although the 1,3-dipolar cycloaddition reaction of azides and alkynes has been known for over a century, the potential of this reaction and its mechanism were only unveiled in the 1960s by Huisgen and co-workers [1]. The catalyst-free 1,3-dipolar Huisgen cycloaddition usually occurs at elevated temperature only in the case of very reactive substrates at ambient temperature, in all cases with prolonged reaction times. The resurgence of recent interest in the reaction has been stimulated by the discovery of the coppercatalyzed version of this process [2], the copper-catalyzed azidealkyne cycloaddition (CuAAC) (Scheme 1) [3].

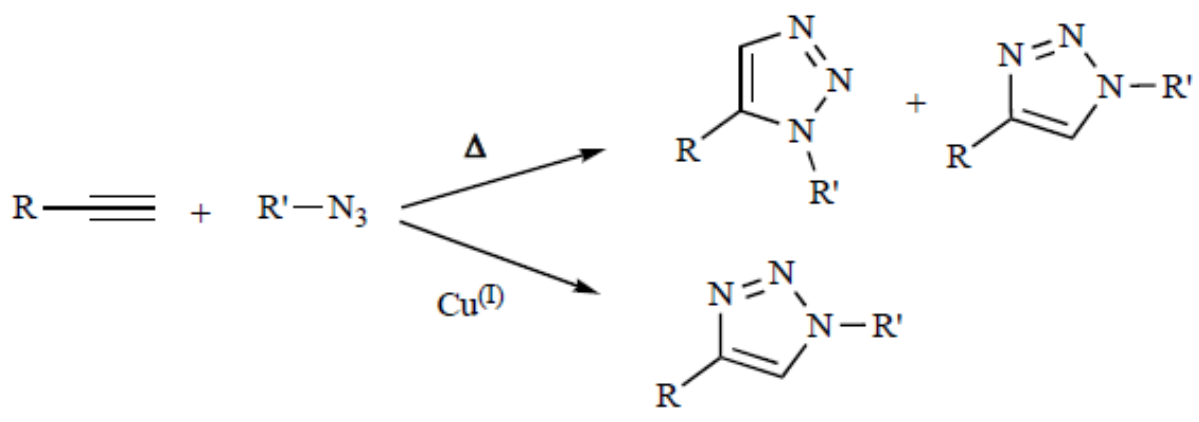

Scheme 1. General reaction scheme of 1,3-dipolar Huisgen cycloaddition.

What makes CuAAC so appealing is its application to label molecules of interest in complex biological samples without interference with any other chemical functionalities. Click chemistry has been shown to be able to directly link chemistry to biology, becoming a true interdisciplinary reaction with extremely wide applicability. CuAAC has been successfully used to immobilize small 
molecules onto macromolecular structures or biopolymers as well as to join lipids or sugars to peptides and proteins also forming macrocyclic structures. Moreover the triazole formed is essentially chemically inert to the most common reaction conditions (i.e. oxi-dation, reduction, hydrolysis, etc.). The different applications of triazole chemistry have previously been extensively reviewed in a range of excellent reviews. In 2003 Kolb and Sharpless presented a review outlining the special nature of triazole chemistry with an emphasis on the potential use of the reaction in biochemical studies and drug discovery [4]. Bock et al. presented a review with a broad analysis of the reaction in 2006 including mechanistic and methodological aspects [5]. Gil et al. [6], Li et al. [7], Moses and Moorhouse [8], and Wu and Fokin [9] have reviewed the general synthetic utility of click chemistry across the fields. In 2008 Meldal and Tornøe published an impressive in-depth literature survey onCuAAC, an erudite review with a comprehensive state of the art of the reaction and all its applications [3]. Other reviews mention the CuAAC as essential in important specific fields. Recently Du Prez et al. presented a rich collection of applications in the synthesis of industrially relevant polymers prepared by step-growth polymerization [10]. Binder et al. [11], Lutz [12] and Lahann et al. [13] described the polymer and materials science applications in excellent surveys. Several reviews documented the exponential growing interest in CuAAC for synthetic applications [14-16]. Interesting collections described applications in the synthesis of peptidomimetics $[17,18]$, and in bioconjugation [19-21] as well as in combinatorial drug discovery $[22,23]$.

Recently Schinazi et al. presented the synthesis of a large number of modified nucleosides and oligonucleotides with a broad range of applications. 1,2,3-Triazoles were applied as bioisosteres or active moieties, and as a linker to a solid support or to form probes and bioconjugates [24].
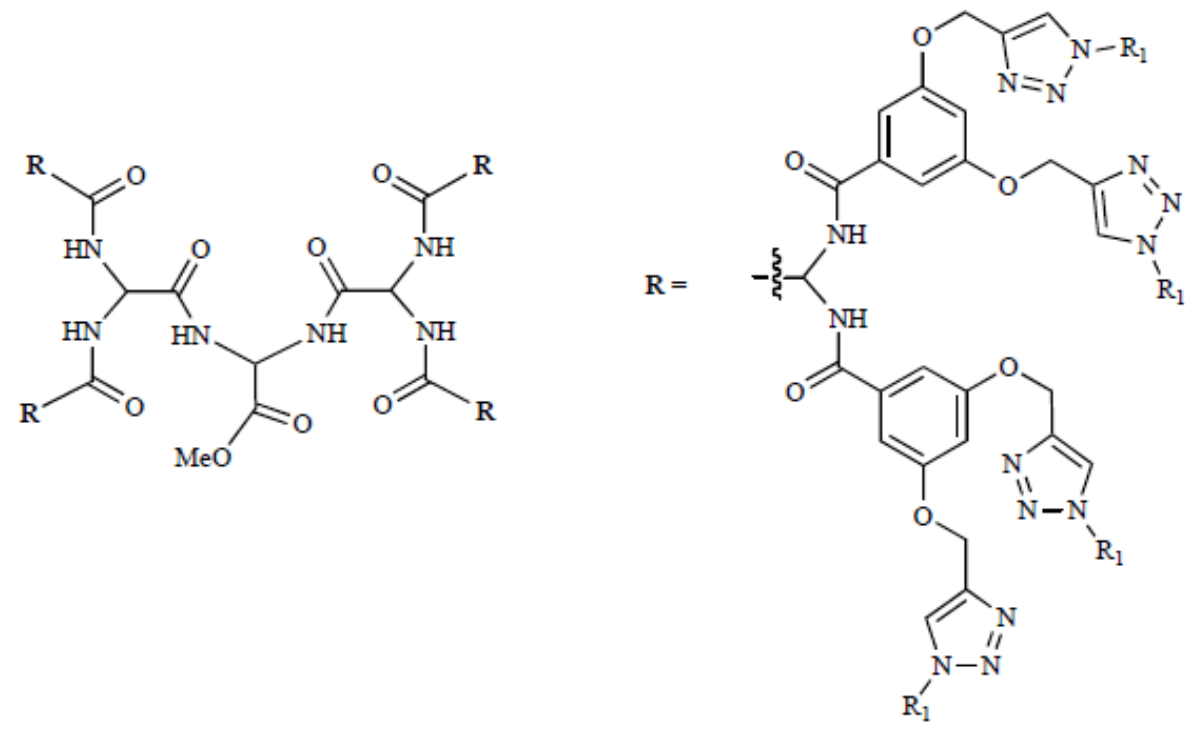

Scheme 2. Schematic representation of 4 th generation peptide dendrimer.

Although the onset of click chemistry and bioorthogonal reactions represents a recent advancement, the advantages of these technologies have rapidly become apparent, and they have become entrenched in the fabric of chemical biology as discussed in the recent review authored by Best [25]. Tron et al. accurately described the accomplishments of this reaction in medicinal chemistry in which click-chemistry might be extremely relevant in the future [26]. 
Other works highlight the developments in carbohydrate-based drug discovery and glycobiology [27] in proteomics probes [28] and in a niche sector such as the preparation of rotaxanes and catenane [29].

It is clear that nowadays no chemist would open the old discussion whether click chemistry is a miracle tool or an ephemeral trend.

CuAAC can be strongly accelerated by microwave (MW) irradiation. Several authors have described excellent yields, high purity and short reaction times: from days to hours and from hours to minutes. Power ultrasound also can promote the reaction, especially under heterogeneous catalysis. Recently metallic copper was used as the sole catalyst under sonochemical conditions, an efficient protocol that fully exploits the effect of acoustic cavitation on the metal surface [30].

The collection of references for the present review was terminated June 30, 2009, and may be considered comprehensive till August 2009. Its aim is to offer a useful update on the outstanding potential applicability of MW- and US-promoted CuAAC.

\section{MACROMOLECULAR SUBSTRATES}

\subsection{Peptides and Peptidomimetics}

The synthesis of multimeric peptides and peptidomimetcs, as well as their dendrimers, draws great advantages from MW-assisted CuAAC. First, second, third and fourth generation dendrimers (Scheme 2) have been synthesized by Liskamp's group starting from bis-propinoxybenzoic acid and suitable azidoacid or azidopeptide [31]. The $\mathrm{Cu}(\mathrm{I})$ catalyzed reaction $\left(\mathrm{CuSO}_{4} / \mathrm{Na}\right.$-ascorbate) was dramatically improved in terms of yield (from 56 to 93\%) and reaction time (only $10 \mathrm{~min}$ at $100^{\circ} \mathrm{C}$ ), when performed under MW irradiation.

By using the same strategy, monomeric, dimeric and tetrameric forms of cyclic-RGD (Arg-Gly-Asp tripeptide) were synthesized [32] and conjugated to a radiotracer (Scheme 3).

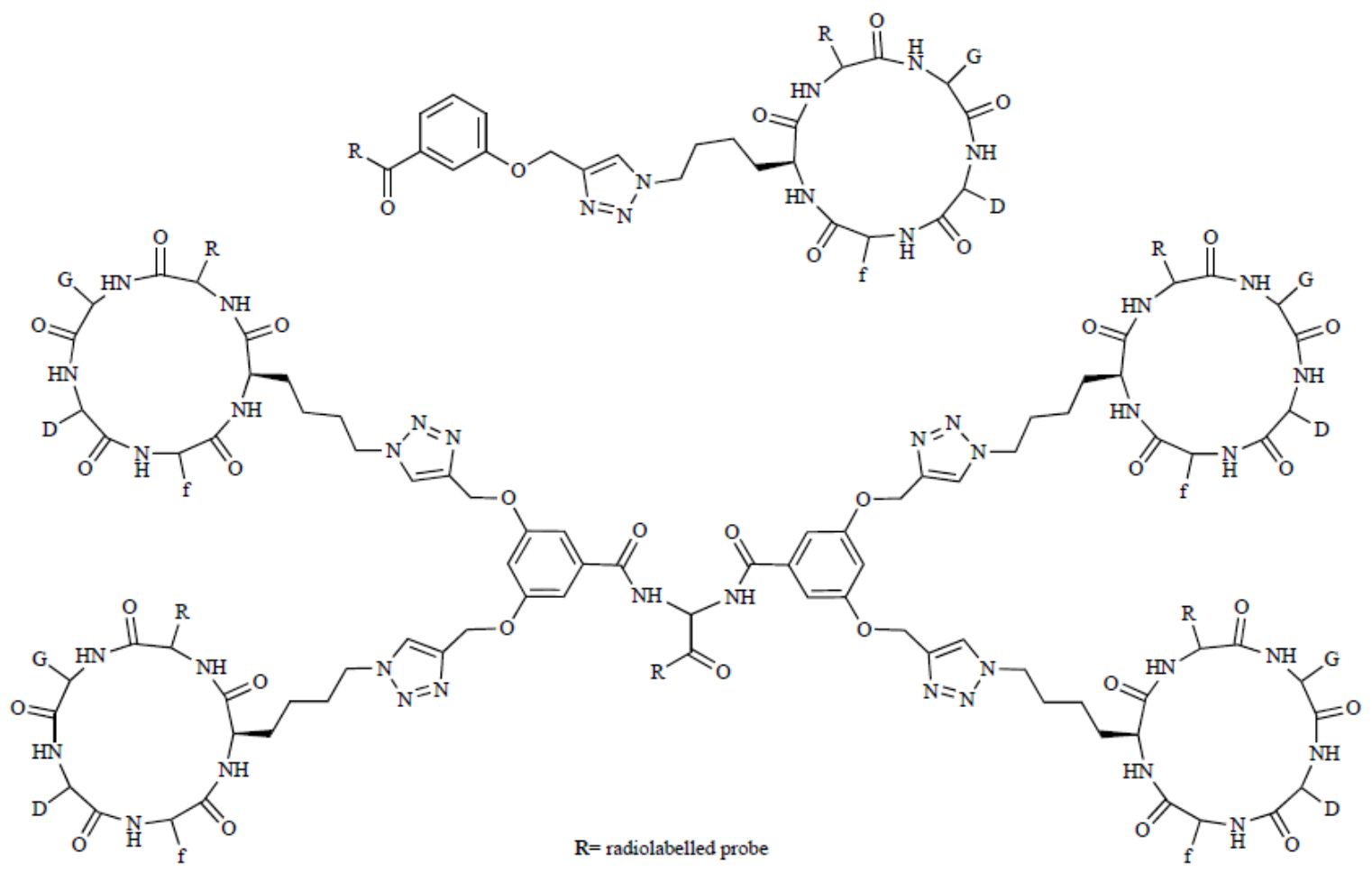

Scheme 3. Monomeric and tetrameric cRGD peptide structure conjugated with a radiolabelled probe. 
The $\mathrm{Cu}(\mathrm{I})$ catalyzed cycloaddition was carried out between an azido derivative of the cyclic-RGD peptide and a dendrimeric alkyne core at $100^{\circ} \mathrm{C}$ under $\mathrm{MW}$. After $10-30 \mathrm{~min}$ of irradiation, the product was isolated in about $57 \%$ yield. The dendrimeric radiolabelled cRGD has shown a markedly higher ability to label cancer cells than the monomeric form.

Substituted 1,2,3-triazole could be used both as a stable and selective cross-linker for bioconjugation, and as a non-hydrolysable isoster of the peptidic bond. Furthermore, 1,2,3-triazol scaffold introduces a well defined constraint in the peptidomimetic's secondary structure. Fmocprotected small peptidomimetics have been prepared with a MW-assisted 1,3 dipolar cycloaddition between a Fmoc-protected amino-azide and an acetylenic amide in presence of $\mathrm{CuI}$ [33]. Reactions were carried out in solvent-free condition, dispersing all reagents and the catalyst on alumina and irradiating the mixture for 20 minutes (three steps: 5, 10, $5 \mathrm{~min}$ ). Final triazoles containing peptidomimetics have been recovered after silica-gel chromatography in $26-71 \%$ yield, depending on the steric hindrance of the starting material (Scheme 4).

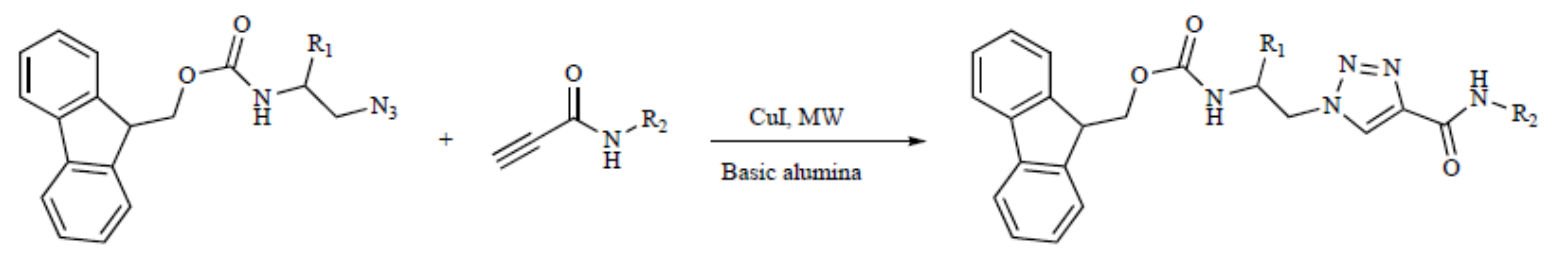

Scheme 4. Fmoc-protected peptidomimetic; the triazole unit has been used as amidic bond isoster.

Solution-phase synthesis of triazole-based peptidomimetic has been achieved by a one pot, two step procedure [34] (Scheme 5).<smiles>COC(=O)C(N)[18OH]</smiles>

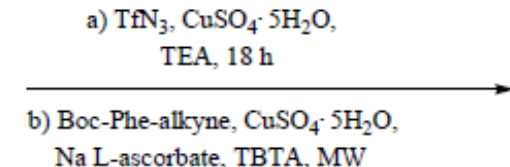<smiles>COC(=O)[C@H]([18OH])n1cc(C([18OH])[18OH])nn1</smiles>

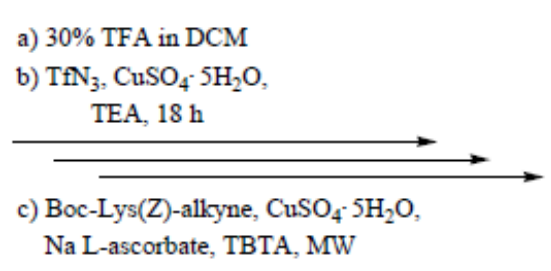

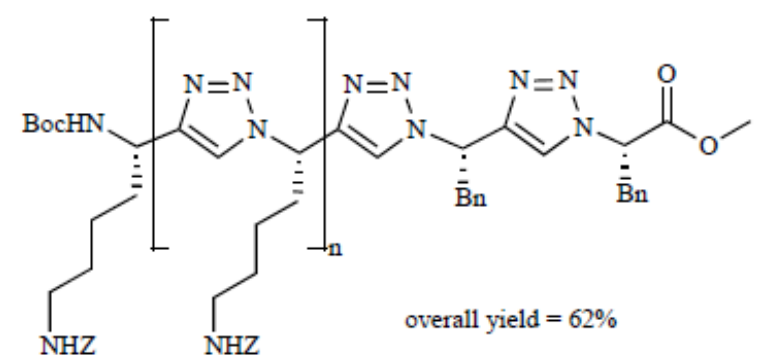

Scheme 5. One-pot sequential synthesis of triazol trimers peptidomimetics.

The first step consists in a metal catalyzed diazotranfer to convert the selected aminoacid (with the carboxylic function protected as methyl ester) into an azide intermediate, then azido-acid has been used in $\mathrm{MW}$-enhanced $\mathrm{CuAAC}$ with the suitable N-Boc-aminoalkyne to obtain the triazole linkage. After the Boc cleavage, the procedure can be repeated in order to grow the peptidomimetic. This sequential protocol gave high yields (over 90\%); a typical procedure requires about $1.5 \mathrm{~h}$ (RT) to 
obtain the azido intermediate and further 5 minutes, under $\mathrm{MW}$ irradiation $\left(80^{\circ} \mathrm{C}\right)$ for the cycloaddition.

Regiospecific CuAAC, can be efficiently applied to the synthesis of peptide-based polymers, a useful tool for drug delivery systems, scaffolds for tissue engineering and repair, and as novel biomaterials.

A model dipeptide azido-phenylalanyl-alanyl-propargyl amide has been efficiently converted into high molecular weight amino acid-based polymers (up to 45,000 Da) with a MW promoted CuAAC [35]. Depending on the reaction conditions, large linear polymers (up to 300 amino acid residues) or medium-sized cyclic peptide (4-20 amino acid residues) can be obtained [35] (Scheme 6).

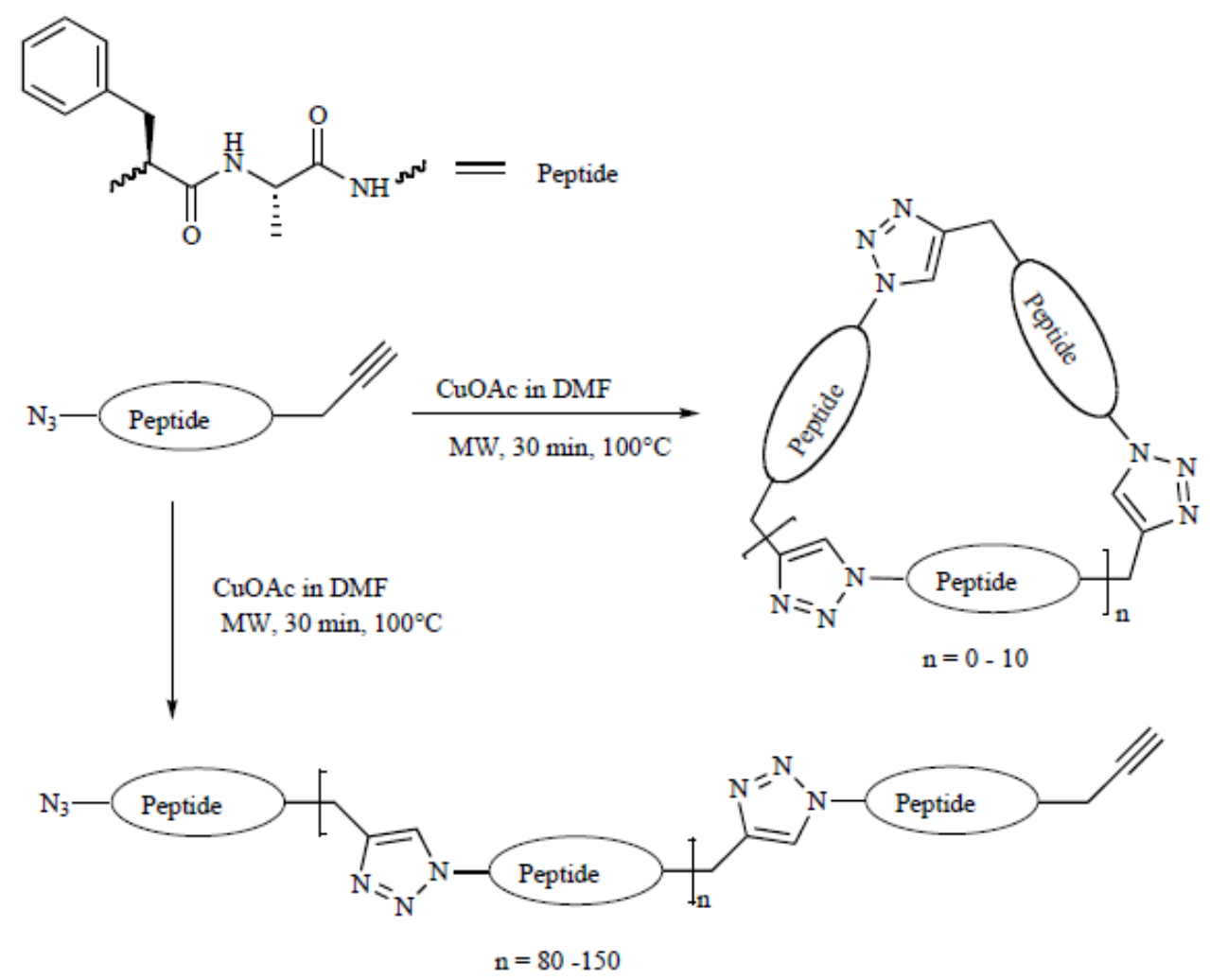

Scheme 6. Structures of linear and cyclic triazole-peptide trimers.

The selectivity of CuAAC allows the link of monomeric peptides which expose unprotected functional groups as amino, mercapto, hydroxy and carboxylic groups [36]. The dielectric heating strongly reduces the reaction time and increases the polymer length that is superior to that obtained under conventional heating.

\subsection{Oligonucleotides and DNA Like Simpler Molecules}

Particularly interesting is the use of this reaction to modify nucleotides or nucleic acid [37, 38, 39] in order to obtain triplexforming oligonucleotides (TFOs), which are promising therapeutics and tools for bio-nanotechnology, or to synthesize peptide nucleic acid (PNA), or again to anchor DNA on solid support and to prepare cyclic DNA.

The insertion of an alkyne moiety along the DNA sequence allows an easy post-synthetic derivatization, in fact, by using $\mathrm{MW}$ enhanced $\mathrm{CuAAC}$ it is possible to conjugate to a fully deprotected DNA sequence a wide variety of aryl/alkyl azides [37] (Scheme 7). 
<smiles>[R]NN</smiles><smiles></smiles>

Scheme 7. DNA derivatization with MW-promoted CuAAC.

$\mathrm{Cu}(\mathrm{I})$-catalyzed reaction is speeded up by MW irradiation, under this condition only two minutes (at $70^{\circ} \mathrm{C}$ ) suffice to bring the reaction to completion (yields up to $45 \%$ ). Further irradiation neither increases the yields nor forms by-products. The same reaction under conventional heating produces the desired compound in about $30 \%$ yield after $24 \mathrm{~h}$. CuAAC was also exploited in the preparation of oligonucleotides where the phosphate linkage was replaced with a triazole unit (Scheme 8).
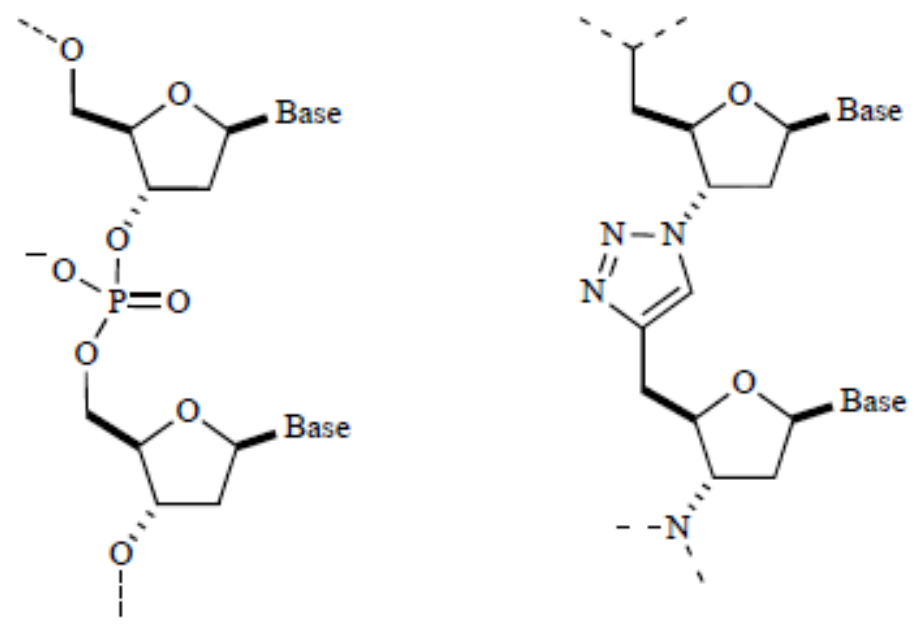

Scheme 8. Triazole bridges can be used instead of phosphate bridges in the preparation of oligonucleotides.

The polymerization reaction in solution (THF) at room temperature occurred in $15 \mathrm{~h}(76-82 \%$ yield), whereas when the systemis anchored on a solid support and irradiated with $\mathrm{MW}\left(50^{\circ} \mathrm{C}\right)$ the coupling reaction takes place in only 90 minutes with the same yield. The combination of solid phase synthesis and MW irradiation makes this polymerization much faster.

On the contrary the cyclization of oligonucleotides with MW promoted click reaction seems to be more efficient when it is carried out in solution than in solid phase [39]. MW irradiation increases the reaction rate and markedly reduces the formation of degradation by-products if compared with conventional heating. Branched and bisbranched cyclic oligonucleotides were prepared following this strategy. 


\subsection{Saccharide Conjugation, Oligo- and Polysaccharides}

Glycosilated aminoacids can be used as building blocks in the solid phase synthesis of glycosilated peptides, the sugar unit can be linked to the aminoacidic residue by an alkyl or aminoalcohol chain or by 1,2,3-triazole bridge [40]. Azido-alkyne glucose has been

prepared and reacted with alkyne aminoacid in the presence of $(\mathrm{EtO})_{3} \mathrm{PCuI}$, with or without MW irradiation, obtaining the glycosilated aminoacid in $60 \%$ yield besides several by-products. Azidoalkyne glucose can, of course, react with itself giving a cyclic dimer or a linear oligomer. Cyclic sugar dimers have been obtained by 1,3-dipolar cycloaddition of azido-alkyne glucose in the presence of $(\mathrm{EtO})_{3} \mathrm{PCuI}$ and triethylamine [40]; in this case $\mathrm{MW}$ irradiation resulted in a reduction of reaction times but also in the decomposition of starting material. In a different study, the possibility to conjugate sugars (mono and disaccharides) to a given structure has been tested on ethynylpyrazinones [41]. The 1,3-dipolar cycloaddition between ethynylpyrazinone and azido saccharide has been carried out in the presence of copper turnings, $\mathrm{CuSO}_{4}$ and TBTA (N,N,Ntris[(1-benzyl-1H-1,2,3-triazol-4-yl)methyl]amine ligand), using a THF/water (1:1) mixture as solvent under MW irradiation $\left(85^{\circ} \mathrm{C}, 10-12 \mathrm{~min}\right.$ ), with excellent yields (up to $90 \%$ ).

CuAAC can be efficiently used to conjugate an azidofunctionalized galactoside with a suitable alkyne-bearing oligonucleotide [42]. The MW-promoted reaction can be performed on a solid support or in solution under similar conditions, at $60{ }^{\circ} \mathrm{C}$ for $20 \mathrm{~min}$ (Scheme 9).

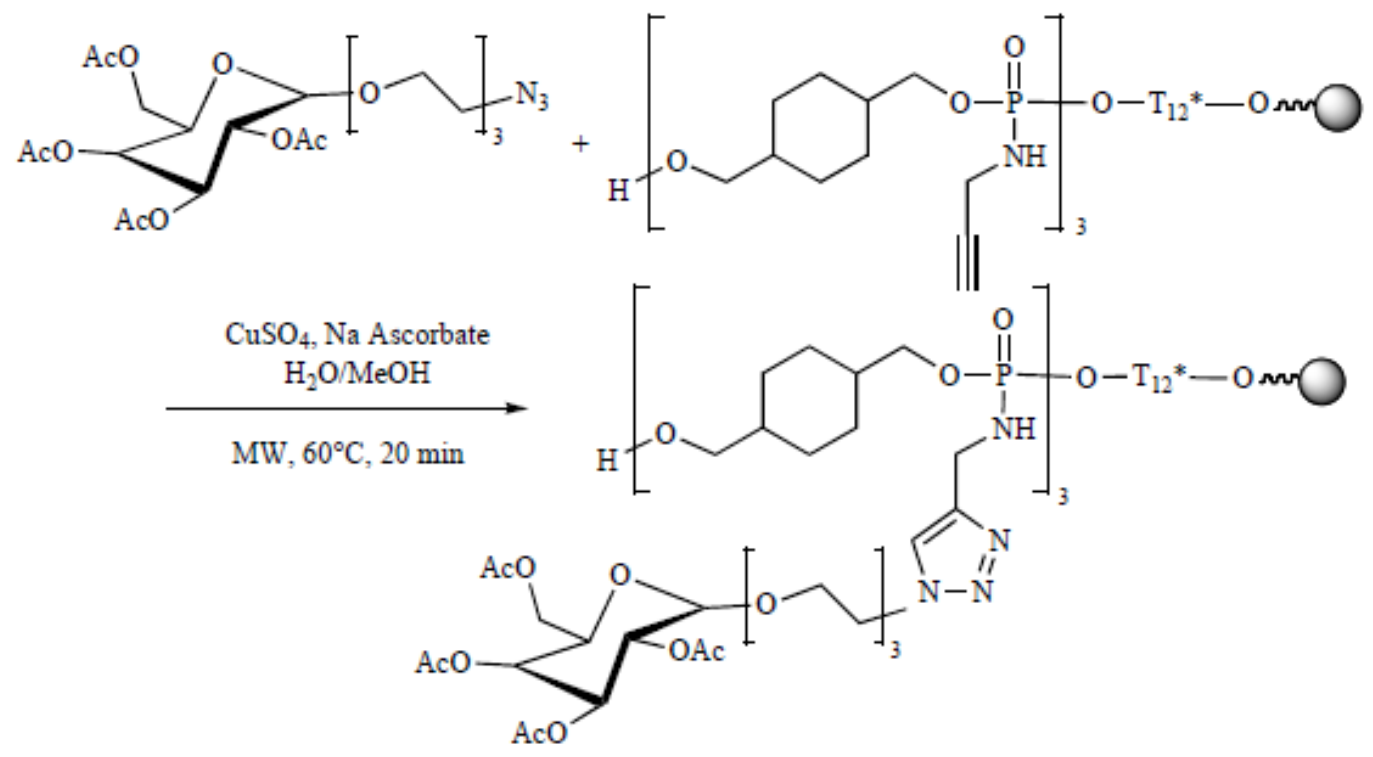

Scheme 9. Solid-phase conjugation of tris-propargylphosphoramidate oligonucleotide to galactosyl azide by MW-assisted Huisgen cycloaddition.

Solid-supported MW assisted click chemistry has shown a lot of advantages: (1) introduction of several alkynes anywhere within the oligonucleotide backbone; (2) cycloadditions can be easily performed with an oligonucleotide on a solid support; (3) use and recovery of excess azide derivatives; (4) conjugation of various azides to an oligonucleotide using this approach; (5) rapid and highyielding multiple 1,3-dipolar cycloadditions without hydrolysis of the phosphoramidate bonds.

A similar approach has been followed to obtain DNA based glycoclusters [43, 44]. Propargylated pentaerythrityl phosphodiester oligomers (Scheme 10), obtained by using a DNA synthesizer with a bis-propargylated pentaerythritol-based phosphoramidite, and suitable azido-sugars, had been conjugated by $\mathrm{CuAAC}$ to obtain the desired glycocluster. Cycloadditions were carried out under MW irradiation at $60^{\circ} \mathrm{C}(30 \mathrm{~min})$. 


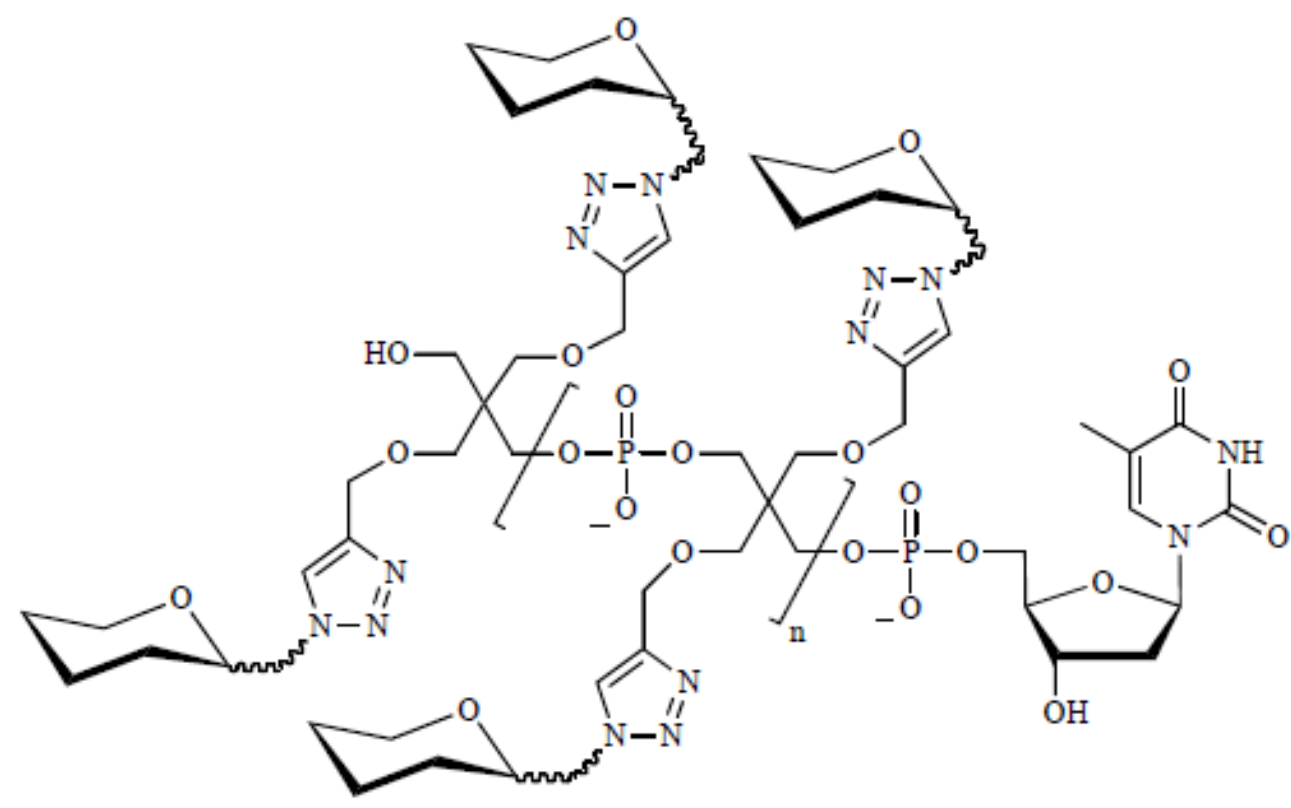

Scheme 10. Schematic representation of polyglycosylated pentaerythrityl phosphodiester oligomer.

A tetra-azido calix[4]arene derivative (Scheme 11) has been used as a substrate able to react with ethynyl tetra-O-benzyl-Cgalactoside, in the presence of $\mathrm{CuI}$ and i- $\mathrm{Pr}_{2} \mathrm{EtN}$, and form a glycocluster [45].

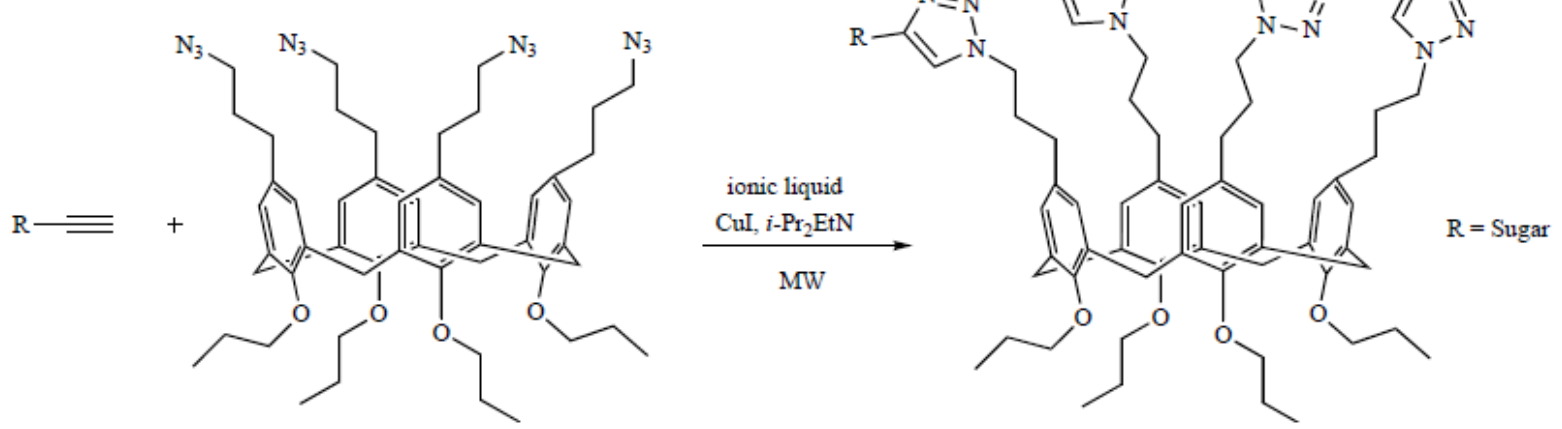

Scheme 11. Conjugation of alkyne-derived sugar to tetraazido calyx [4]arene core by MW-promoted CuAAC.

The optimized reaction conditions include the use of ionic liquids under $\mathrm{MW}$ irradiation $\left(80^{\circ} \mathrm{C}, 2 \mathrm{~h}\right)$, with reaction yields up to $90 \%$. In this case the improvement provided by MW is only in terms of reaction time, in fact yields and the presence of byproducts do not change when conventional heating is used. Ionic liquids are excellent solvents and strongly adsorb MW, two features that make them the solvent of choice for this kind of reactions.

A tetra-azido calix[4]arene scaffold has been conjugated, in another study [46], with alkyne aminoacids, dipeptide and carbohydrate under MW irradiation in the presence of $\mathrm{CuSO}_{4}$ an ascorbic acid. Cycloaddition products have been obtained in good to excellent yields (40-89\%). The same 
protocol has been applied to 1,3- diazidometilenecalix[4]arenes obtaining the 1,3-difunctionalized products in moderate to good yields (30-50\%) (Scheme 12).

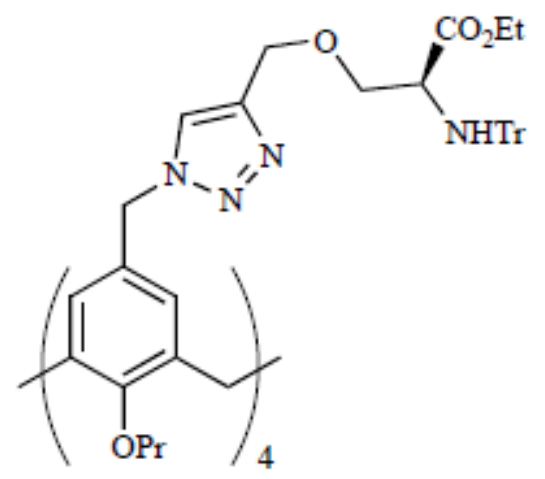

Scheme 12. Schematic representation of calyx[4]arene aminoacidic derivative obtained by MWpromoted click chemistry approach.

Glycodendrimers are a different kind of glycoclusters. The conjugation of sugars to the dendrimeric core can be obtained by CuAAC [47], like previously reported calixarene examples. A dendrimeric poly-alkyne core has been treated with suitable azidosugar, in DMF/H2O and CuSO4/ascorbic acid, under MW $\left(80^{\circ} \mathrm{C}, 20 \mathrm{~min}\right)$, with yields higher than $95 \%$ (Scheme 13). MW irradiation not only increases the reaction rate, mainly it promotes completely conjugation; in fact, under conventional conditions not all acetylene residues are involved in cycloaddition, giving a mixture of products.
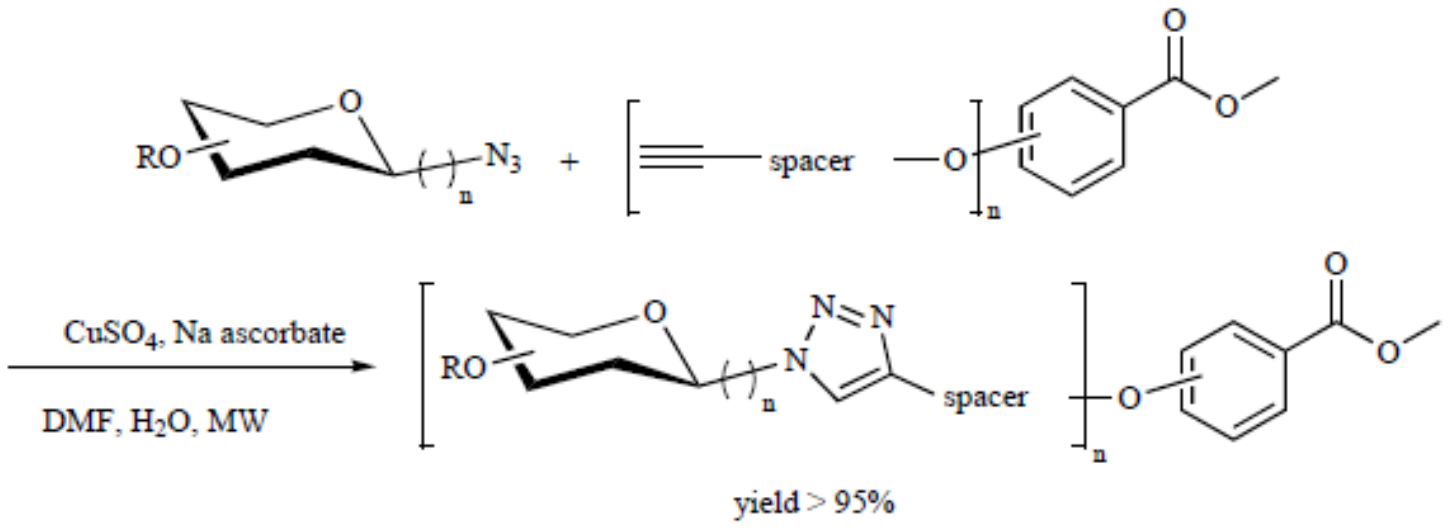

Scheme 13. MW-promoted, $\mathrm{Cu}(\mathrm{I})$ catalyzed synthesis of triazole glycodendrimers.

The same poly-alkyne cores have been used in the preparation of peptide dimers, tetramers, and octamers. Standard solid phase peptide synthesis has been used to prepare the antibacterial manganin 2 peptide with $\mathrm{N}$ - or C-terminal azido functionalities. Then the mixture of azido-peptide an poly-alkyne core with $\mathrm{CuSO}_{4} /$ ascorbic acid as catalyst has been heated with $\mathrm{MW}\left(80^{\circ} \mathrm{C}\right.$, $\mathrm{DMF} / \mathrm{H}_{2} \mathrm{O}$ mixture, $20 \mathrm{~min}$ ) to obtain the dendrimeric peptides [48].

Sugar heterodimers can be obtained by coupling of alkyne and azido derivatives with yields under dielectric heating and $\left(\mathrm{Ph}_{3} \mathrm{P}\right)_{3} \mathrm{CuBr}$ or $(\mathrm{EtO})_{3} \mathrm{PCuI}$ as a catalyst (yield 99\%) [49]. In this case the authors have chosen these particular catalysts because of their air stability and easy and inexpensive preparation. The combination of MW irradiation with these stable and efficient catalysts also allows the preparation of monovalent and heptavalent glycocyclodexrins. 
Monoazido and perazido cyclodextrins have been efficiently conjugated to propargyl and thiopropargyl mannose (Scheme 14).

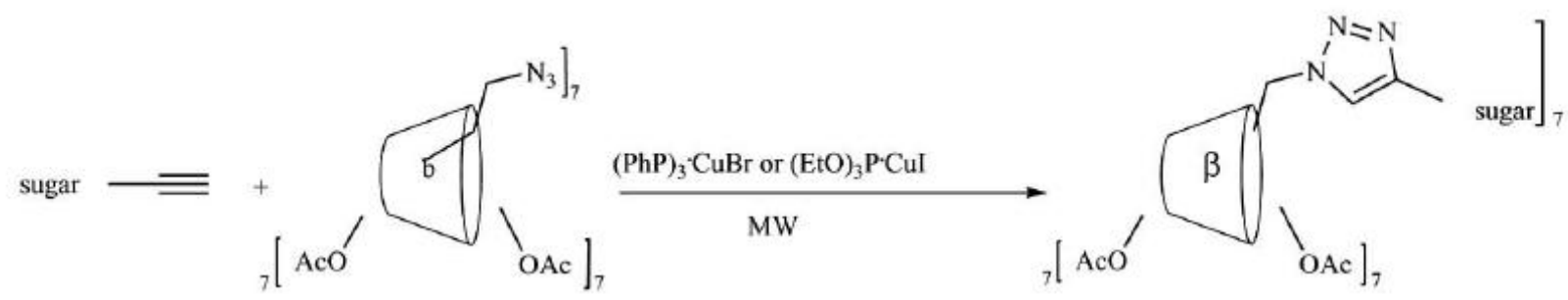

Scheme 14. Synthesis of heptaglycosiltriazolyl cyclodextrin derivative via $\mathrm{MW}$-promoted, $\mathrm{Cu}(\mathrm{I})$ mediated 1,3-dipolar cycloaddition.

Monoazidocyclodextrin has been also used in 1,3-dipolar cycloaddition with 1,3,5-tris propargylossibenzene (Scheme 15) in order to form a cyclodextrin trimer [50]. The reaction has been carried out in DMSO, under MW irradiation $\left(80^{\circ} \mathrm{C}, 1 \mathrm{~h}\right)$, using $\mathrm{CuI}$ as a catalyst in the presence of DIPEA. $\mathrm{Cu}(\mathrm{I})$ has been removed from reaction mixture by forming a $\mathrm{Cu}(\mathrm{II})$ complex with EDTA.

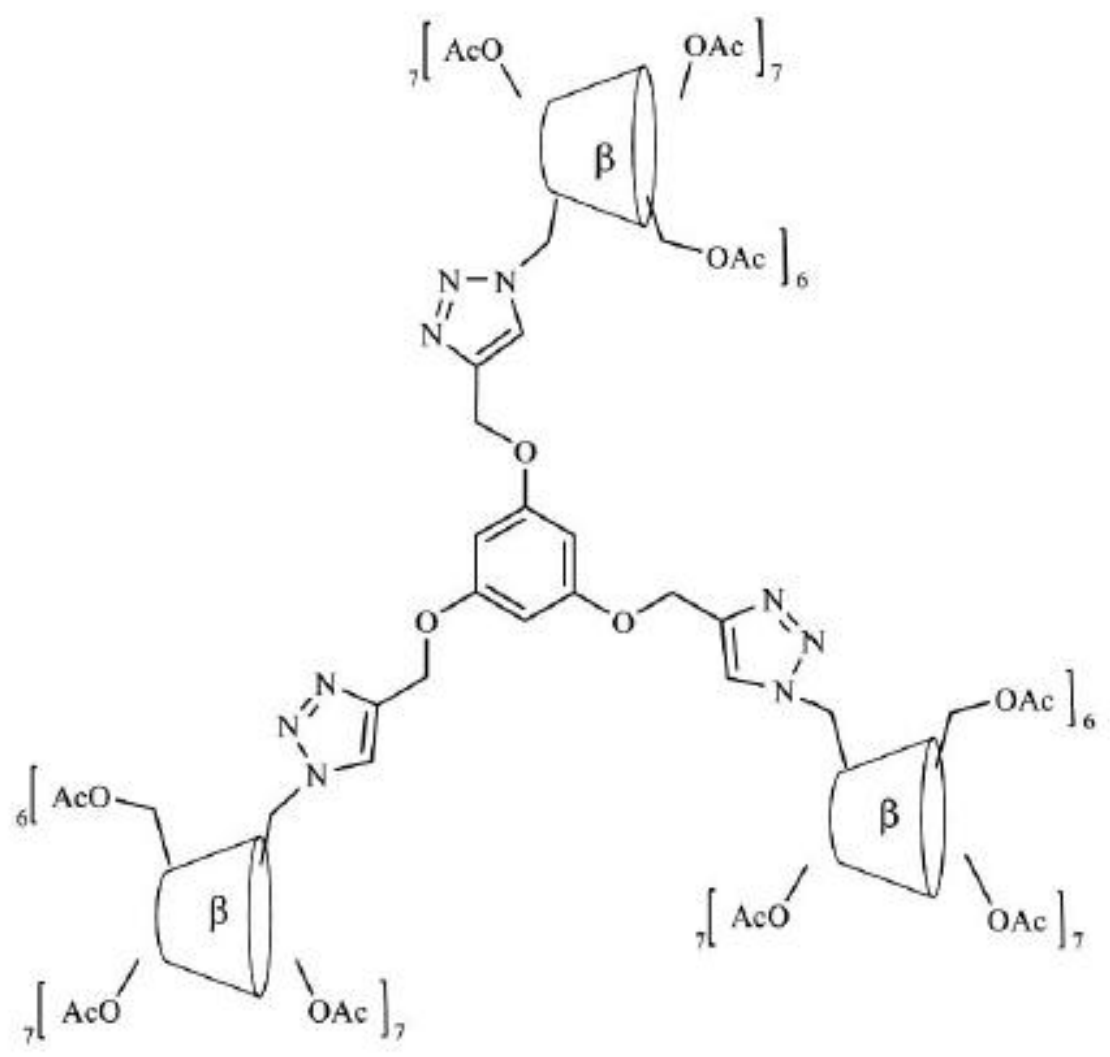

Scheme 15. Schematic representation of $\beta$-cyclodextrin trimer obtained by MW-enhanced click reaction.

A wide library of CD dimers and trimers has been prepared using a similar approach [51, 52]. In these studies CD units have been joined 'head-to-head', 'head-to-tail' and 'tail-to-tail' through 1,2,3 triazole spacers. Two different strategies have been adopted by authors, the first consists in direct reaction between two $C D$ derivatives bearing an azido and an alkyne group respectively; the second one used a bifunctional spacer as a linker. MW-assisted reactions with the CuSO4/ascorbic acid 
catalytic system, were fast and with good yields. Different $\beta$-CDs trimers have also been prepared following the same procedure by reacting dipropargylated $\beta$-CD and 6-monoazido- $\beta C D$ (Scheme 16); despite the use of a MW heating system the reaction, carried out in a $\mathrm{H}_{2} \mathrm{O} / \mathrm{t}-\mathrm{BuOH}$ mixture, did not produce a satisfactory yield, however when the solvent mixture was replaced with DMF, the final products were isolated in good yield (70\%). The same authors described several CuAAC performed under heterogeneous catalysis with charcoal-supported $\mathrm{Cu}(\mathrm{I})$ prepared under US irradiation [53]. Best results were obtained under simultaneous MW/US irradiation, achieved by inserting into the MW oven a non-metallic US horn [54].
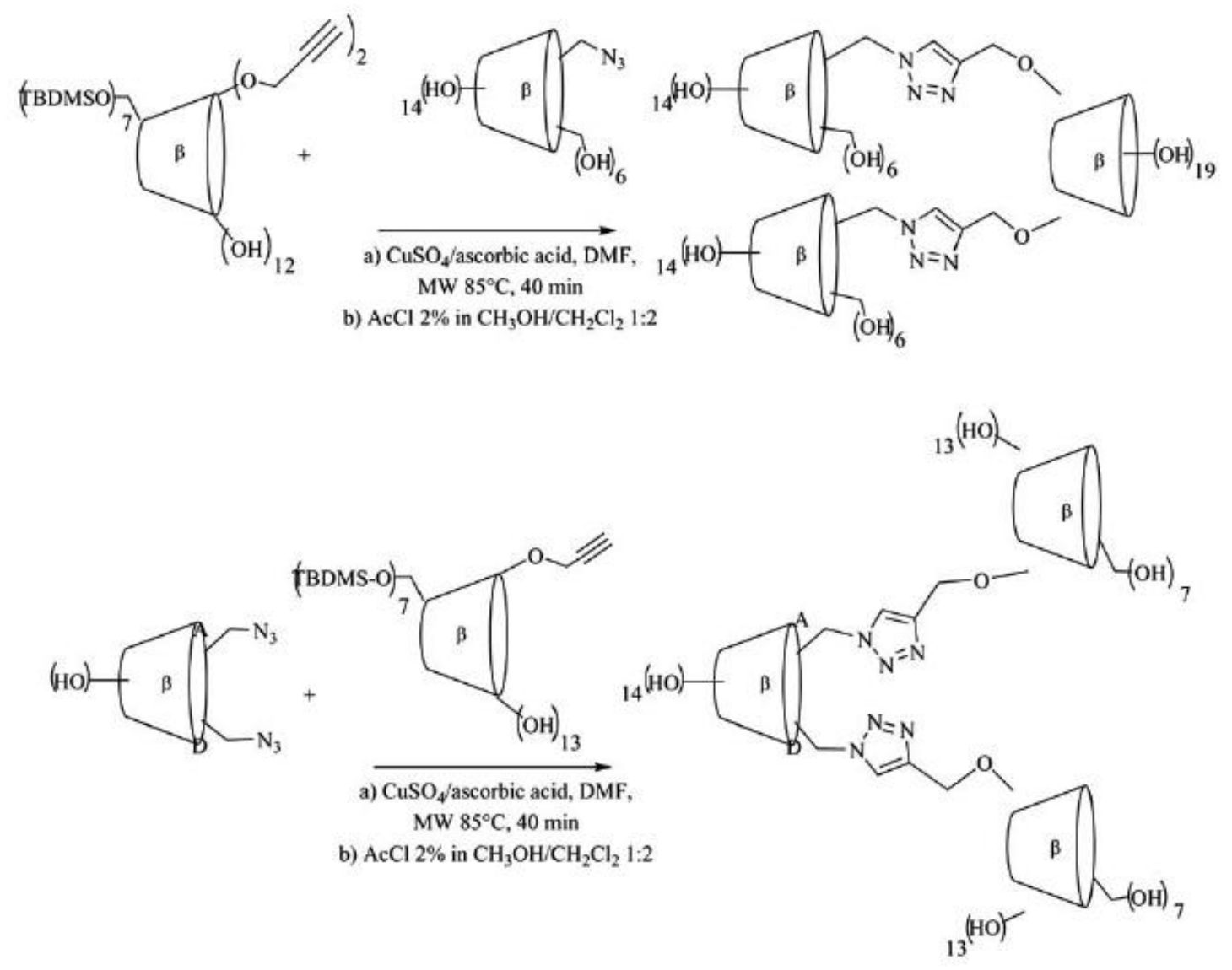

Scheme 16. Synthesis of two different types of $\beta$-cyclodextrin trimers through CuAAC.

CDs dimers have been also obtained by reacting 6(I)-azido- $\beta C D$ with 1,7 -octadiyne in the presence of $\mathrm{Cu}(\mathrm{I})$ and under MW irradiation [55]. The reaction between azido-CD and diyne was not completed under MW irradiation; a mixture of CD dimer and alkyne-CD derivative was obtained. The alkyne $\mathrm{CD}$ derivative was further exploited to link this moiety, again by CuAAC, with an azido-adamantane giving a CD-adamatane unit which self assembles originating a supramolecular CD dimer (Scheme 17). 

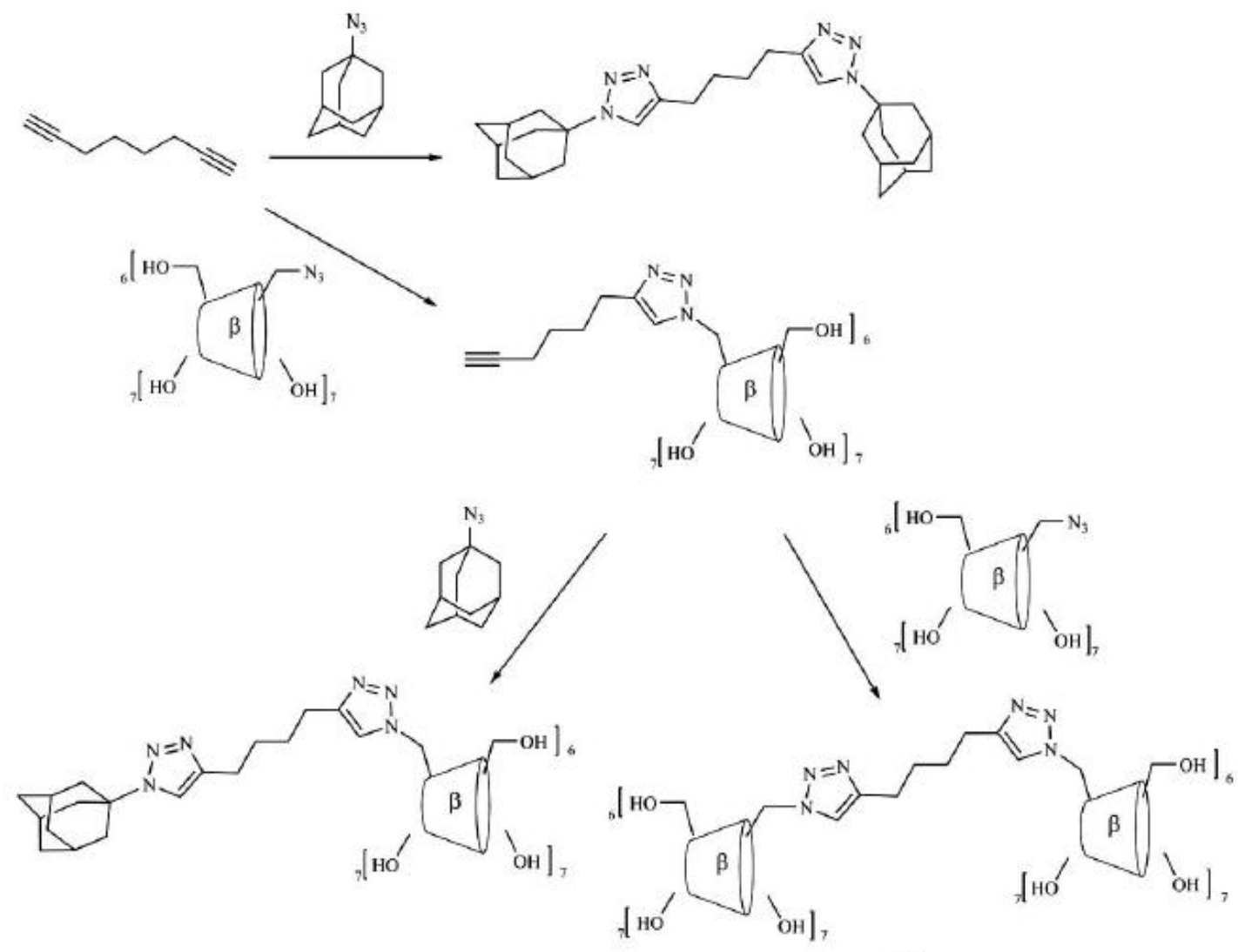

(a)

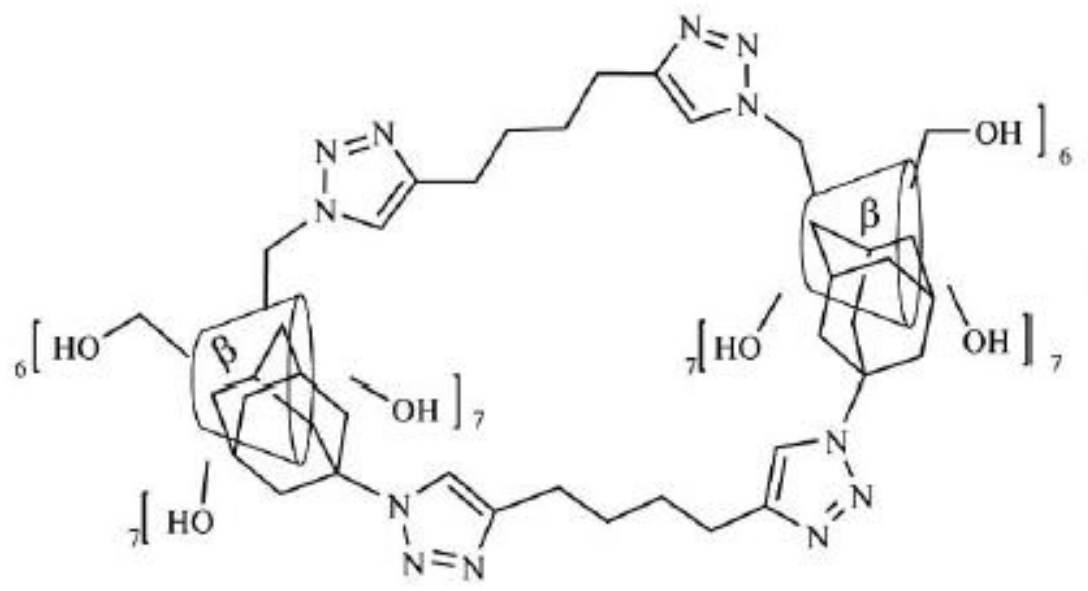

(b)

Scheme 17. MW-promoted synthesis of covalent (a) and supramolecular $\square$-cyclodextrin dimers. 
Heptakis-azido- $\beta$-cyclodextrin has been conjugated, via $\mathrm{CuAAC}$, with seven polymeric chains derivatized with alkyne moiety obtaining a star-shaped polymer [56]. The reaction has been carried out in DMF, under MW irradiation $\left(100^{\circ} \mathrm{C}\right.$, for $\left.15 \mathrm{~min}\right)$.

\subsection{Miscellaneous}

CuAAC has been successfully used for the conjugation of different moieties to gold nanoparticles [57] (Scheme 18). Dielectric heating cut down reaction time to 10 minutes giving excellent yields (78-100\%). Highly activated alkynes are more reactive and require less catalyst loading (CuSO4/ascorbic acid) than less or nonactivated analogues. Particularly interesting is the synthesis of Pd catalyst immobilized on gold nanoparticles: a Pd complex, functionalized with an alkyne moiety, has been reacted with poli-azido gold nanoparticles using the previously described method with a $85 \%$ yield.

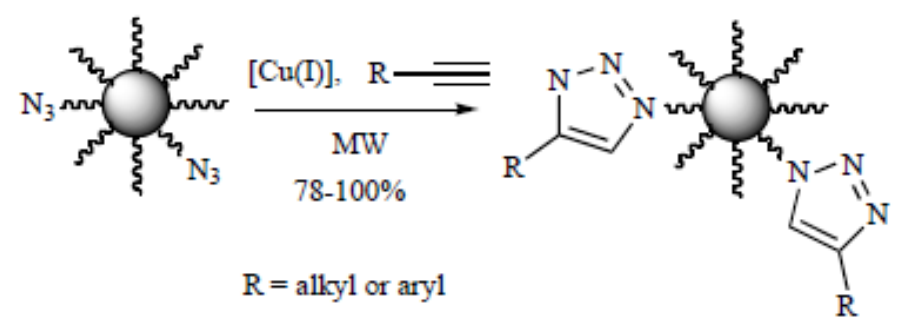
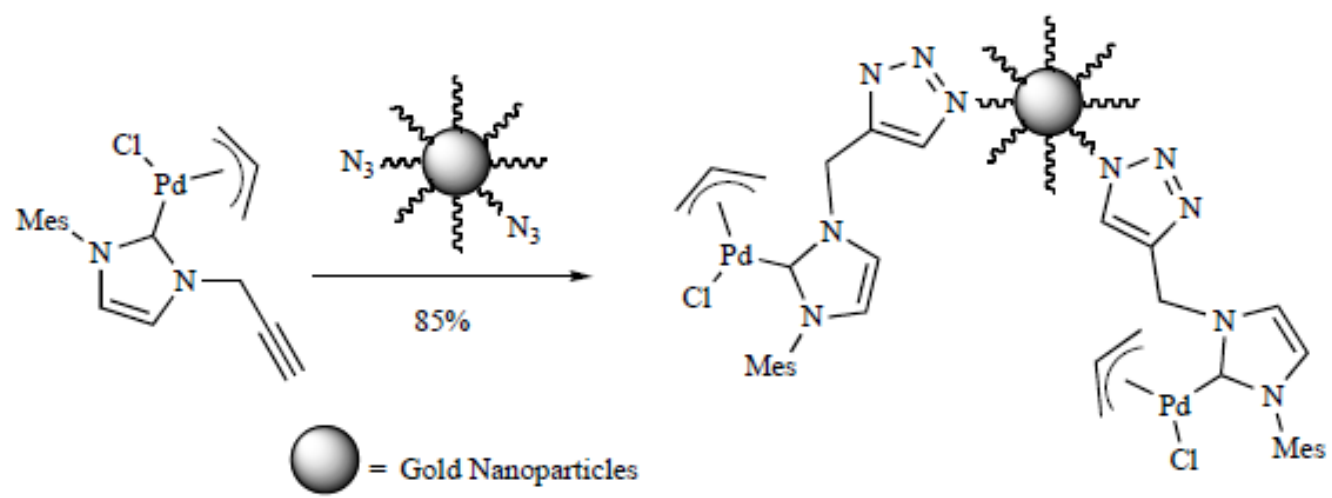

Scheme 18. MW-promoted click reaction applied to gold nanoparticles.

Finally, polyamide-based dendrimer mono-functionalized with alkyne or azide units have been quantitatively conjugated, by MWpromoted CuAAC to different groups (Scheme 19). 

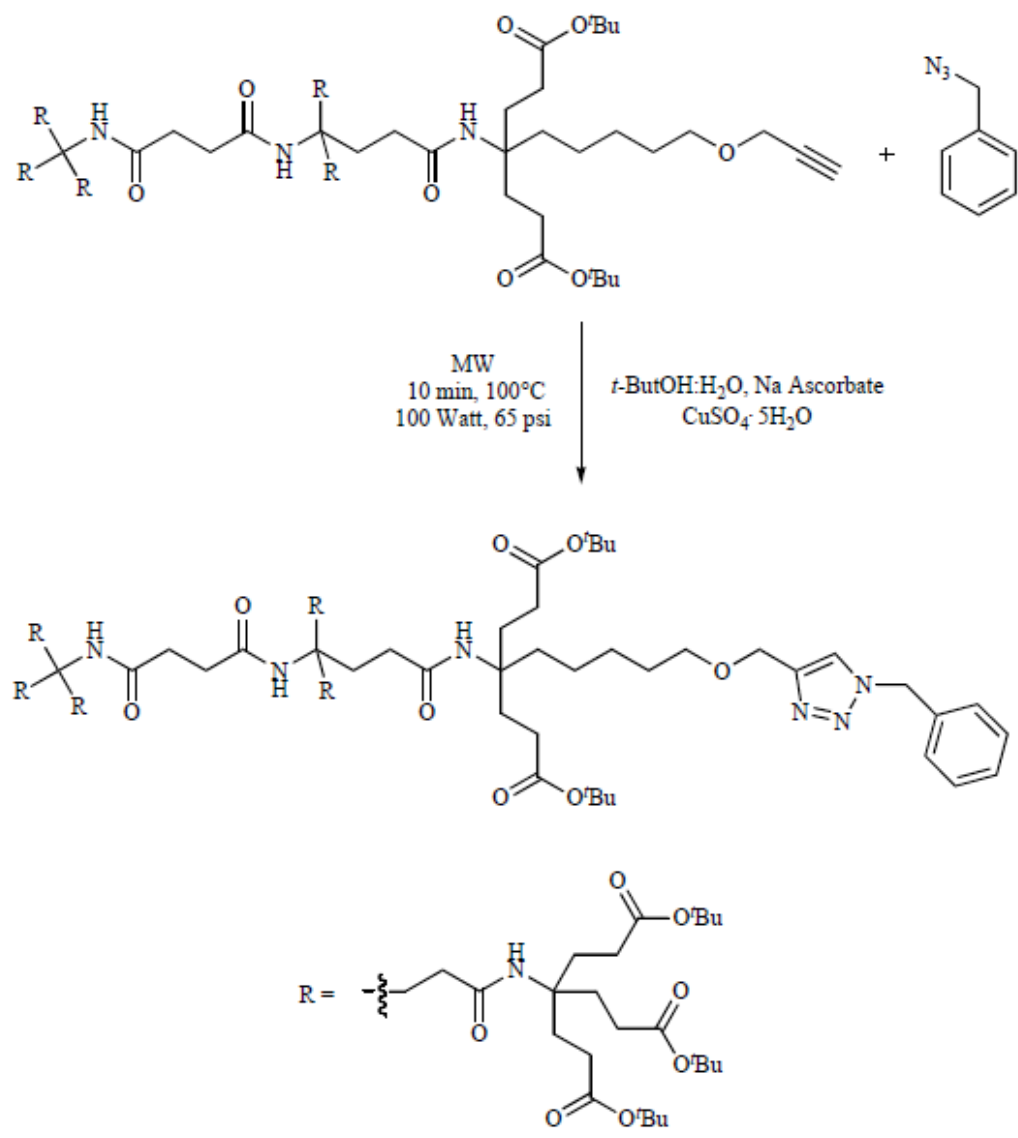

Scheme 19. Dendrimer conjugation by MW-promoted CuAAC.

The reaction, carried out in $\mathrm{t}-\mathrm{BuOH} / \mathrm{H}_{2} \mathrm{O} 1 / 1$, in the presence of $\mathrm{Cu}(\mathrm{I})\left(\mathrm{CuSO}_{4} /\right.$ ascorbic acid), takes 10 minutes under $\mathrm{MW}$ irradiation at $100^{\circ} \mathrm{C}$, instead of $20 \mathrm{~h}$ under conventional heating conditions. In all cases reaction yields were almost quantitative.

\section{SMALL MOLECULES}

\subsection{Nucleoside and Nucleotide Triazole Derivatives and Analogues}

A triazolic cycle has been used in the synthesis of nucleoside derivatives: 1,4- and 1,5-disubstituted1,2,3-triazole-nucleosides have been obtained from various alkynes with 1'azido-2',3',5', tri-Oacetylribose using either copper-catalyzed or rutheniumcatalyzed azide-alkyne respectively [58]. In this study $\mathrm{Cu}$-catalyzed reactions have been carried out only under classical heating, whereas the $\mathrm{Ru}$-catalyzed reactions (with the commercially available [Cp* $\mathrm{RuCl}(\mathrm{PPh} 3) 2]$ ) have been carried out under both conventional and dielectric heating (Scheme 20). MW irradiation promotes these reactions cutting down reaction times, from 6 hours to 5 minutes, and increasing reaction yield (up to $95 \%$ ). MW-promoted, $\mathrm{Ru}$-catalyzed reactions are highly regioselective, the ratio1,5/1,4disubstituted triazoles has always been estimated higher than 95:5. 

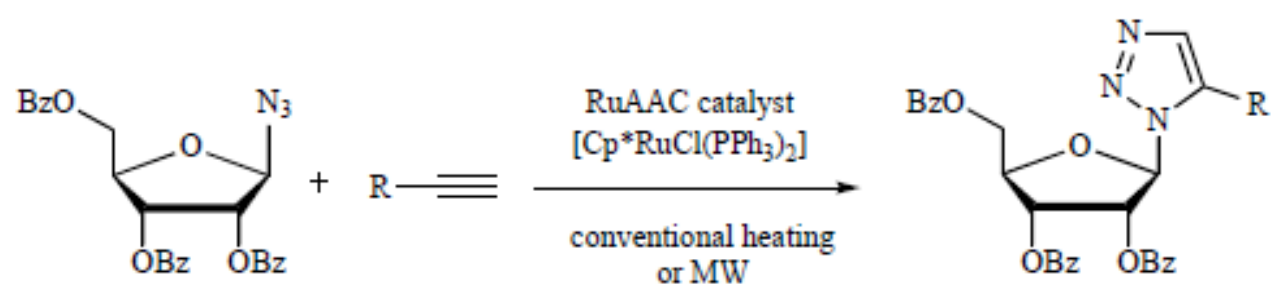

Scheme 20. MW-promoted Ru-catalyzed synthesis of triazolyl nucleosides.

$\mathrm{Ru}$-catalyzed click reactions have also been the object of another study in which the authors have subjected aryl amines to cycloaddition with aryl acetylenes. In this case $[\mathrm{Cp} * \mathrm{RuCl}]_{4}$ was a better catalyst than $\left[\mathrm{Cp} * \mathrm{RuCl}\left(\mathrm{PPh}_{3}\right)_{2}\right][59]$.

Similar 4-substituted triazolyl-nucleosides have been obtained from suitably protected azido ribose [60] or deoxyribose [61] and different acetylene derivatives, by solvent-free MW-promoted CuAAC (Scheme 21), or in $\mathrm{CH}_{2} \mathrm{Cl}_{2}$ solution by conventional heating in the presence of acetic acid. In the first case, all the reactants have been dispersed on $\mathrm{SiO}_{2}$ and then irradiated with $\mathrm{MW}$ at $110^{\circ} \mathrm{C}$ for 1 min obtaining the desired products in $95 \%$ yields. Although the acidic condition $\left(\mathrm{SiO}_{2}\right.$ or acetic acid) favour the reaction, the role of Brønsted acid in the reaction mechanism has not yet been clarified.

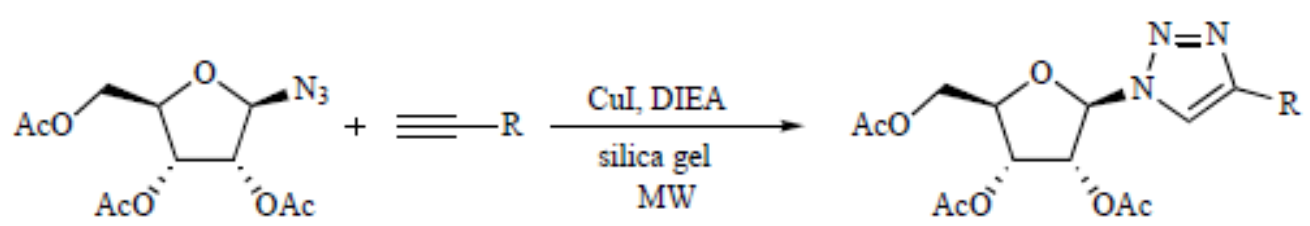

Scheme 21. MW-promoted, solvent-free, $\mathrm{Cu}(\mathrm{I})$-catalyzed synthesis of triazolyl nucleosides.

Similar systems have been reported in which furo[2,3-b]pyrazines are linked to the sugar moiety by means of a triazole bridge [62]. In this case $\mathrm{Cu}(\mathrm{I})$ has been produced in situ from $\mathrm{Cu}(0)$ and $\mathrm{CuSO}_{4}$, $\mathrm{N}, \mathrm{N}, \mathrm{N}$-tris[(1-benzyl-1H-1,2,3-triazol-4-yl)methyl] amine (TBTA) has been used as the ligand for $\mathrm{Cu}(\mathrm{I})$. Reaction yields higher than $85 \%$ have been obtained under MW irradiation conditions (5-10 min, $\left.90^{\circ} \mathrm{C}\right)$. Replacing sugars with 2-azido-4,4-bis-hydroxymethylcyclopentanole [63, 64] carbanucleosides can be obtained (Scheme 22).

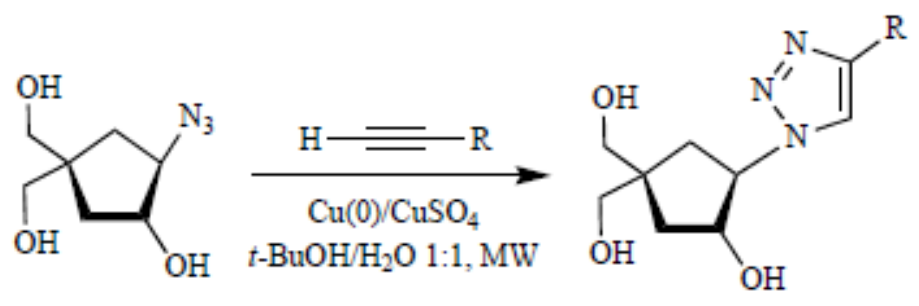

Scheme 22. Carbanucleosides synthesis via MW-promoted CuAAC.

Under MW irradiation in $\mathrm{t}-\mathrm{BuOH} / \mathrm{H}_{2} \mathrm{O} 1: 1$ mixture and $\mathrm{Cu}(0) / \mathrm{CuSO}_{4}$, reaction times were ranging from instantaneous conversion up to $1 \mathrm{~h}$. Different sources of $\mathrm{Cu}(\mathrm{I})$ have been tested in this study, tetrakis(acetonitrile)copper hexafluorophosphate $\left(\left[\mathrm{Cu}\left(\mathrm{CH}_{3} \mathrm{CN}\right)_{4}\right] \mathrm{PF}_{6}\right)$ and imidazoline(mesythyl) copper bromide (Imes) $\mathrm{CuBr}$, however the best catalyst remain the typical $\mathrm{Cu}(0) / \mathrm{CuSO}_{4}$ mixture. 
A slightly different azido carbocycle has been used for the same purposes in another study [65]. Complete conversion has been achieved under $\mathrm{MW}$ using $\mathrm{Cu}(0) / \mathrm{CuSO}_{4}$ pair in $\mathrm{t}-\mathrm{BuOH} / \mathrm{H}_{2} \mathrm{O}(15$ $\min$ at $125^{\circ} \mathrm{C}$ ).

The 1,4-disubstituted-1,2,3-triazole has been also used as a linker in the synthesis of non-natural thymidine dimers [66], and oligomers [67] as depicted in Scheme 23.

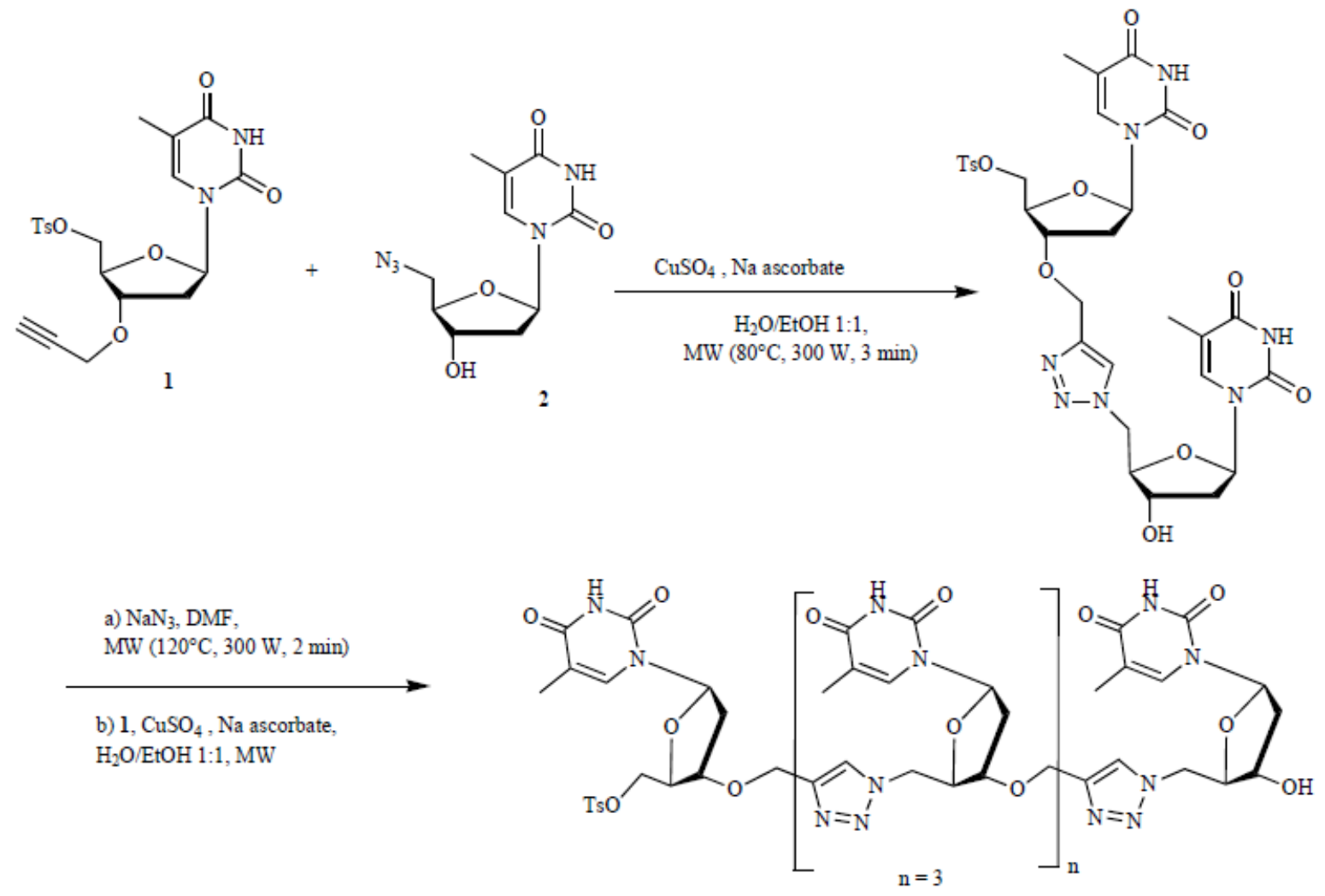

Scheme 23. Non-natural nucleosides oligomers via MW-promoted CuAAC.

These kind of oligomers can resist chemical or enzymatic depolymerization and maintain the directional character of DNA strands. To this aim two different thymidine derivatives have been synthesized: one with an azido group in the position 5 of the ribose unit and the other with a propargyloxy pendant arm on position 3 of the ribose unit. $\mathrm{CuI}$ or $\mathrm{CuSO}_{4} /$ ascorbic acid 1,3-dipolar cycloaddition between the two thymidine units gave the desired thymidine dimer. Also in this study MW irradiation strongly reduces reaction times (from $5 \mathrm{~h}$ to $3 \mathrm{~min}$ ) increasing the reaction yield (from 61 to 85\%) [66]. In order to obtain thymidine oligomers the same protocol has to be repeated several times. In this case the propargyl thymidine has a tosyl group on the position 5 of the sugar. After the cycloaddition the tosilate can be converted into the azido group and subjected to further cycloaddition [67].

\subsection{Miscellaneous}

Ethynylpyrazinone has been conjugated with different azides by MW-promoted CuAAC [68]. The $\mathrm{Cu}(\mathrm{I})$ catalyst has been produced in situ using copper wires and $\mathrm{CuSO}_{4}$ (Scheme 24). The reaction proceeds at r.t. in about 36 hours, while under MW irradiation $\left(100^{\circ} \mathrm{C}\right)$ the reaction time has been reduced to $15 \mathrm{~min}$, and after the addition of TBTA to only $5 \mathrm{~min}$. 
<smiles></smiles><smiles>[R]c1ccc([N+]([O-])([O-])[O-])cc1</smiles><smiles>[R]c1ccc(-n2cc(COc3nc(Cl)cn(Cc4ccc(OC)cc4)c3=O)nn2)cc1</smiles>
Cu wires, $\mathrm{CuSO}_{4}$,
$\mathrm{MW}(100 \mathrm{~W})$<smiles>N#CC(CN)(CO)CO</smiles><smiles>COc1ccc(Cn2c(C)c(Cl)nc(OCc3cnn[nH]3)c2=O)cc1</smiles><smiles>[2H]c1c(Cl)nc(OCc2cn(CC(CO)(CO)CNNC)nn2)c(=O)n1Cc1ccc(OC)cc1</smiles>

Scheme 24. MW-promoted CuAAC between propargyloxypyrazinone derivative and various azides.

The [1,5-a]azocine skeleton (which can be used as a scaffold for aza-analogues of (-)-steganacin, a potent antileukemic and tubulin polymerization inhibitor) has been obtained by a one-pot reaction based on MW-assisted Suzuki-Miyaura cross-coupling and further MW-promoted CuAAC [69, 70]. The latter was performed in DMF at $120^{\circ} \mathrm{C}$ giving the target molecule in acceptable yield (59\%) (Scheme 25). Particularly interesting is the stereochemistry of these three consecutive reactions, in fact, after final intramolecular cyclization, only one diastereoisomer has been obtained; this high diastereoselectivity during ring closure could probably be explained by the high steric hindrance around the biaryl axis.<smiles>[R]C#CC(N[R])c1cc([R4])ccc1-c1ccc([R4])cc1CN</smiles>
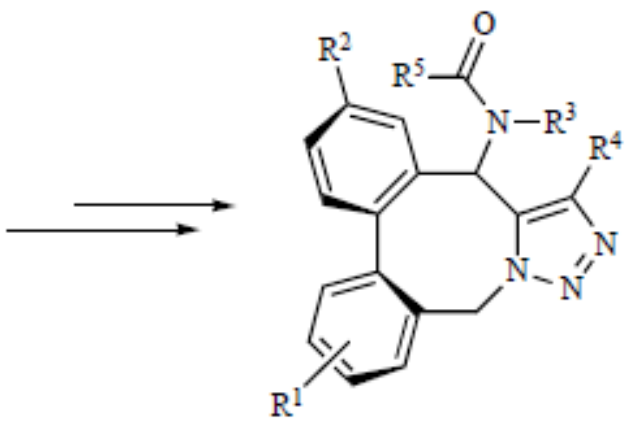

Scheme 25. Synthesis of azocine derivative via MW-promoted CuAAC. 
A very interesting one-pot tandem azidation-cycoaddition procedure has been developed by Moorhouse and Moses [8]. Aromatic anilines has been efficiently converted, in situ in aromatic azides by reaction with t-butylnitrite and trimethylsilylazide in acetonitrile; complete conversion has been reached in less than $30 \mathrm{~min}$ at r.t. (in most of the cases in only 5 minutes). After complete azide formation, $\mathrm{CuSO}_{4}$ and ascorbic acid have been added followed by a terminal alkyne. 1,3dipolar cycloaddition has been carried out under $\mathrm{MW}$ irradiation at $80^{\circ} \mathrm{C}$ in less than 10 minutes. This procedure is of particular interest for reasons of safety (organic azides are toxic and explosive) and ease of execution; it works particularly well with all electron-poor anilines and both electronrich and electronpoor terminal alkynes. Similar results have been obtained when the authors prepared in situ, the alkyl azide by the reaction of $\mathrm{NaN}_{3}$ with proper alkyl halide which has been reacted with suitable terminal alkynes (Scheme 26) [71].
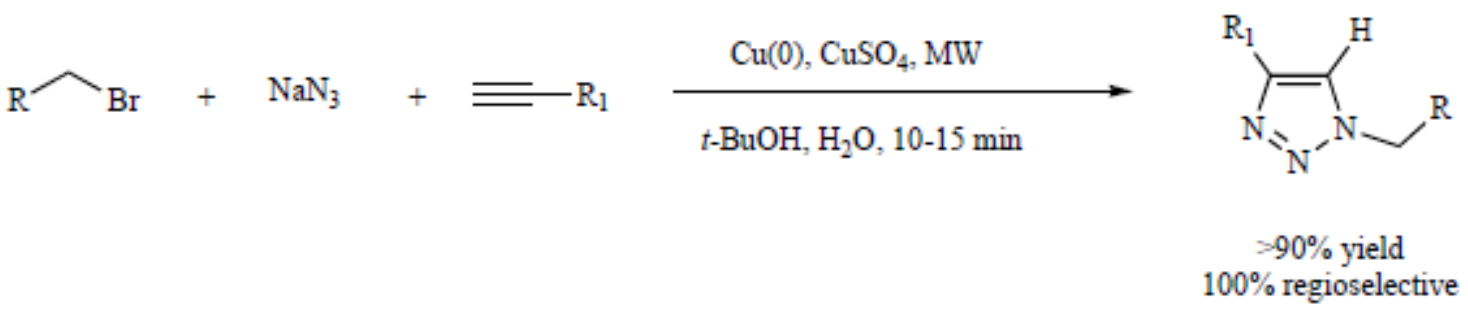

Scheme 26. Triazole synthesis via three-component MW-promoted CuAAC.

MW irradiation dramatically decreases reaction time from hour to minutes $\left(125^{\circ} \mathrm{C}, \mathrm{t}-\mathrm{BuOH} / \mathrm{H}_{2} \mathrm{O}\right.$, $\mathrm{Cu}$ turnings $/ \mathrm{CuSO}_{4}$ ) always in good yields (above $80 \%$ ). The one pot three-component reaction is, also in this case, a powerful tool to synthesize 1,4-disubstituted-1,2,3-triazole without isolating dangerous and unstable alkyl azide.

The previously described $\mathrm{MW}$-promoted, $\mathrm{Cu}(\mathrm{I})$-catalyzed, three-component reaction approach has also been exploited in the synthesis of a small library of enantiomerically pure a-[4-(1-substituted)1,2,3-triazol-4-yl]benzylacetamides (Scheme 27) [72]. MW irradiation $\left(120^{\circ} \mathrm{C}, \mathrm{t}-\mathrm{BuOH} / \mathrm{water}\right.$, $\mathrm{CuSO}_{4} /$ ascorbic acid) allows complete conversion in only 10 min (yield between 75 and 90\%).

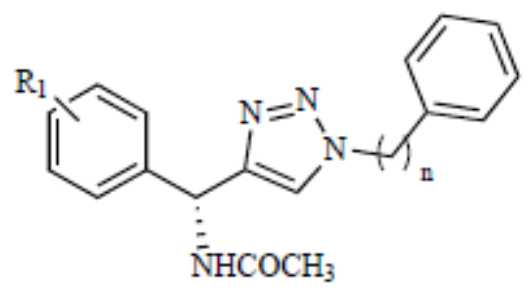

Scheme 27. Schematic representation of [4-(1-substituted)-1,2,3-triazol-4-yl]benzylacetamides.

A different approach to the three-component reaction has been made using ultrasound (US) (Scheme 28) as the energy source [73]. 


$$
\begin{aligned}
& \widehat{R}_{\mathrm{X}}+\mathrm{NaN}_{3}+\mathrm{R}^{\prime} / \underset{\mathrm{US}, 15-30 \mathrm{~min}}{\mathrm{CuI}, \mathrm{H}_{2} \mathrm{O} \text {, r.t. }} \underset{\mathrm{N}}{\longrightarrow} \\
& \mathrm{R}=\mathrm{alkyl}, \text { aryl, allyl } \\
& \mathrm{X}=\mathrm{Cl}, \mathrm{Br}, \mathrm{I} \\
& \mathrm{R}^{\prime}=\text { aromatic, aliphatic }
\end{aligned}
$$

Scheme 28. US-promoted three-component Huisgen cycloaddition.

The best results have been obtained using $\mathrm{CuI}$ in water, under sonochemical conditions (common US cleaning bath) at r.t. for 15- 30 min ( yield 92\%). Lower yields have been obtained with $\mathrm{Cu}(\mathrm{II})$ salts (no regioselective reaction), $\mathrm{Cu}(0)$ (again no regioselective reaction), $\mathrm{Cu}(0) / \mathrm{CuSO}_{4}$ or different $\mathrm{Cu}(\mathrm{I})$ salts.

CuAAC can also be sequentially performed after a Biginelli's multicomponent reaction [74]. Moderate to good yields were obtained after only $1 \mathrm{~min} \mathrm{MW}$ irradiation $\left(80^{\circ} \mathrm{C}\right.$, $\mathrm{DMF}$, $\mathrm{CuSO}_{4} /$ ascorbic acid).

MW-promoted 1,3-dipolar cycloaddition has been efficiently used in the synthesis of triazolylquinolones, to develop new potential fluorescent probes [75] and in the synthesis of highly fluoroalkylate triazoles, to develop new amphiphilic molecules [76].

It is well known that 1,3-dipolar cycloaddition between azide and acetylenic amide requires a long time because of the poor reactivity of the latter. However, 1,2,3-triazoles with an amide substituent are particularly interesting for their biological activity and their direct synthesis it remain an important task. A MW-promoted solvent-free protocol (Scheme 29) has been developed in order to promote this reaction [77] which gives the desired product in good yield (from 62 to $84 \%$ ) in only $30 \min \left(120^{\circ}\right.$ or $\left.170^{\circ} \mathrm{C}\right)$.
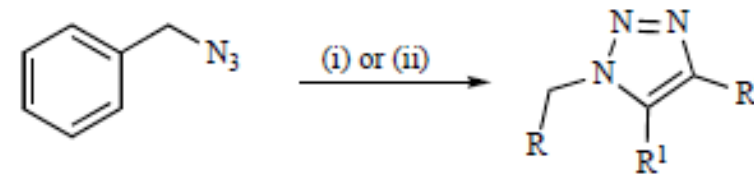<smiles>N#CCCc1ccccc1</smiles><smiles>C#CC(=O)NCP</smiles>

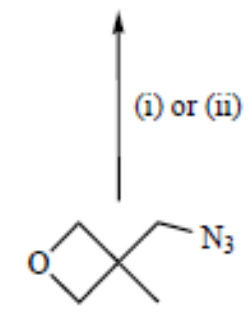<smiles>C#CC(=O)N1CCCCC1</smiles>

$$
\begin{aligned}
& \text { (i) acetylenic amide } 1, \\
& \left.55^{\circ} \mathrm{C} \text {, MW ( } 120 \mathrm{~W}\right), 30 \mathrm{~min} \\
& \text { (ii) acetylenic amide 2, } \\
& 85^{\circ} \mathrm{C} \text {, MW (170 W), } 30 \mathrm{~min}
\end{aligned}
$$

Scheme 29. MW-promoted solvent-free 1,3-dipolar cycloaddition between acetylenic amides and azides.

The authors have extended this method to the preparation of different triazoles from acetylenic amide [78] and also to bistriazole (Scheme 30) coming from both bis-alkyne and mono-azido or mono-alkyne and bis-azido derivatives. The synthesis of bistriazole using mono-azide and bisacetylenic amide has drawn great advantages from the application of the previously described protocol (solvent-free, $55^{\circ} \mathrm{C}, 30 \mathrm{~min}$, yields up to $85 \%$ ), whereas the reaction between bis-azide and acetylenic amide proceeded only to the formation of the mono triazole derivative. To obtain the bis 
derivate the reaction condition had to be changed: namely the reaction has been carried out in toluene, under $\mathrm{MW}$ irradiation $\left(75^{\circ} \mathrm{C}\right)$ using an external cooling system, for 1 hour, yields up to $65 \%$.
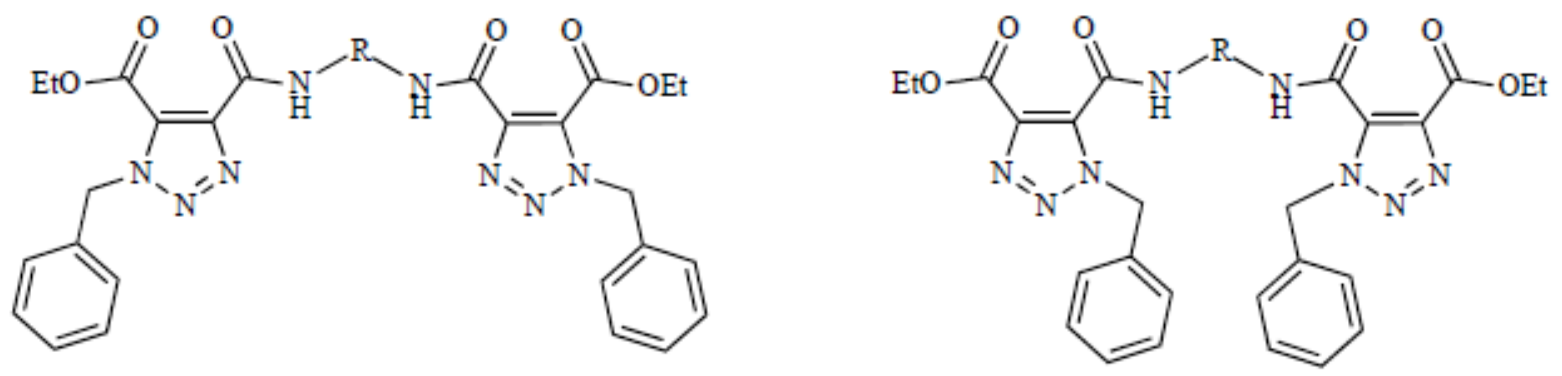

Scheme 30. Schematic representation of bis-triazoles obtained by MW-promoted cycloaddition. Toluene, $75^{\circ} \mathrm{C}$, external cooling system, $1 \mathrm{~h}$.

The effect of MW irradiation, as well as the solvent-free and $\mathrm{LiClO}_{4}$ conditions, have been investigated by Loupy, Palacios and co-workers [79]. In this study the authors highlight the outstanding effect of dielectric heating specially on poorly activated alkynes.

\section{CONCLUSION}

Because of its modularity, its high yields, and its simple conditions and purification procedures, the $\mathrm{CuAAC}$ has been suitable for the synthesis of an enormous number of elaborated molecules that cover the interest of all fields of chemistry. MW- and US-promoted CuAAC knocked down the last limitations in terms of yields and reaction times for the applicability of this reaction.

The exquisite efficiency and reliability, render it an invaluable chemical tool for probing and perturbing also biological systems.

As such, it is clear that MW- and US-promoted CuAAC will act as enabling technologies that will spur the course of challenging future research.

\section{ACKNOWLEDGEMENTS}

This work was supported by the Regione Piemonte and the University of Turin (Project: NanoIGT, Converging Technologies).

\section{REFERENCES}

[1] Huisgen, R. In 1, 3-Dipolar Cycloaddition Chemistry; Padwa, A., Ed.; Wiley: New York, 1984, pp. 1-176.

[2] Rostovtsev, V. V.; Green, L. G.; Fokin, V. V.; Sharpless, K. B. A Stepwise Huisgen Cycloaddition Process: Copper(I)-Catalyzed Regioselective Ligation of Azides and Terminal Alkynes. Angew. Chem., Int. Ed., 2002, 41, 2596-2599.

[3] Meldal, M.; Tornøe C.W. Cu-Catalyzed Azide-Alkyne Cycloaddition. Chem. Rev., 2008, 108, 2952-3015. 
[4] Kolb, H. C.; Sharpless, K. B. The growing impact of click chemistry on drug discovery. Drug Discov. Today, 2003, 8, 1128-1137.

[5] Bock, V. D.; Hiemstra, H.; Van Maarseveen, J. H. CuI-Catalyzed Alkyne-Azide "Click" Cycloadditions from a Mechanistic and Synthetic Perspective. Eur. J. Org. Chem., 2006, 51-68.

[6] Gil, M. V.; Arévalo, M. J.; López, O. Click Chemistry - What's in a Name? Triazole Synthesis and Beyond. Synthesis, 2007, 1589-1620.

[7] Yan, L.; Yong, J.; Yu-Fen, Z. Application of azoles synthesis in bioconjugate chemistry. Chin. J. Org. Chem., 2006, 26, 1640-1645.

[8] Moses, J. E.; Moorhouse, A. D. The growing applications of click chemistry. Chem. Soc. Rev., 2007, 36, 1249-1262.

[9] Wu, P.; Fokin, V. V. Catalytic Azide-Alkyne Cycloaddition: Reactivity and Applications. Aldrichim. Acta, 2007, 40, 7-17.

[10] Billiet, L.; Fournier, D.; Du Prez, F. Step-growth polymerization and 'click' chemistry: The oldest polymers rejuvenated. Polymer, 2009, 50, 3877-3886.

[11] Binder, W. H.; Sachsenhofer, R. "Click" Chemistry in Polymer and Materials Science. Macromol. Rapid Commun., 2007, 28, 15-54.

[12] Lutz, J. F. 1,3-Dipolar Cycloadditions of Azides and Alkynes: A Universal Ligation Tool in Polymer and Materials Science. Angew. Chem., Int. Ed. 2007, 46, 1018-1025.

[13] Nandivada, H.; Jiang, X.; Lahann, J. Click Chemistry: Versatility and Control in the Hands of Materials Scientists. Adv. Mater., 2007, 19(17), 2197-2208.

[14] Goodall, G. W.; Hayes, W. Advances in cycloaddition polymerizations. Chem. Soc. Rev., 2006, $35,280-312$.

[15] Evans, R. A. The rise of azide-alkyne 1,3-dipolar 'click' cycloaddition and its application to polymer science and surface modification. Aust. J. Chem., 2007, 60, 384-395.

[16] Köhn, M.; Breinbauer, R. The Staudinger Ligation - A Gift to Chemical Biology. Angew. Chem., Int. Ed. 2004, 43, 3106-3116.

[17] Kaiser, J.; Kinderman, S. S.; Van Esseveldt, B. C. J.; Van Delft, F. L.; Schoemaker, H. E.; Blaauw, R. H.; Rutjes, F. P. J. T. Synthetic applications of aliphatic unsaturated alpha-H-alphaamino acids. Org. Biomol. Chem., 2005, 3, 3435-3467.

[18] Angell, Y. L.; Burgess, K. ChemInform Abstract: Peptidomimetics via Copper-Catalyzed Azide - Alkyne Cycloadditions. Chem. Soc. Rev., 2007, 36, 1674-1689.

[19] Breinbauer, R.; Köhn, M. Azide-alkyne coupling: A powerful reaction for bioconjugate chemistry. ChemBioChem, 2003, 4, 1147-1149.

[20] Dong, W. L.; Zhao, W. G.; Li, Y. X.; Liu, Z. X.; Li, Z. M. Click chemistry and its applications. Chin. J. Org. Chem., 2006, 26, 271-280. 
[21] Durek, T.; Becker, C. F. W. Protein semi-synthesis: New proteins for functional and structural studies. Biomol. Eng., 2005, 22, 153-172.

[22] Brik, A.; Wu, C. Y.; Wong, C. H. Microtiter plate based chemistry and in situ screening: a useful approach for rapid inhibitor discovery. Org. Biomol. Chem., 2006, 4, 1446-1457.

[23] Groth, T.; Renil, M.; Meinjohanns, E. PEG based resins for protease drug discovery synthesis, screening and analysis of combinatorial on-bead libraries. Comb. Chem. High Throughput Screen., 2003, 6, 589-610.

[24] Amblard, F.; Cho, J. H.; Schinazi, R. F. Cu(I)-Catalyzed Huisgen Azide-Alkyne 1,3-Dipolar Cycloaddition Reaction in Nucleoside, Nucleotide, and Oligonucleotide Chemistry. Chem. Rev., 2009, 109, 4207-4220.

[25] Best, M. D. Click Chemistry and Bioorthogonal Reactions: Unprecedented Selectivity in the Labeling of Biological Molecules. Biochemistry, 2009, 48, 6571-6584.

[26] Tron, G. C.; Pirali, T.; Billington, R. A.; Canonico, P. L.; Sorba, G.; Genazzani, A. A. Click chemistry reactions in medicinal chemistry: Applications of the 1,3-dipolar cycloaddition between azides and alkynes. Med. Res. Rev., 2008, 28(2), 278-308.

[27] Wilkinson, B. L.; Bornaghi, L. F.; Houston, T. A.; Poulsen, S.-A. The growing impact of click chemistry in carbohydrate-based drug discovery, in Drug Design Research Trends. Kaplan, S.P. Ed. Nova Science Publishers, NY. 2007, 57-102.

[28] Salisbury, C. M.; Cravatt, B. F. Click Chemistry-Led Advances in High Content Functional Proteomics. QSAR Comb. Sci., 2007, 26(11-12), 1229-1238.

[29] Miljanic, O. S.; Dichtel, W. R.; Aprahamian, I.; Rohde, R. D.; Agnew, H. D.; Heath, J. R.; Stoddart, J. F. Rotaxanes and catenanes by click chemistry. QSAR Comb. Sci., 2007, 26(11-12), 1165-1174.

[30] Cravotto, G.; Fokin, V. V.; Garella, D.; Binello, A.; Boffa, L.; Barge, A. Ultrasound-promoted copper-catalyzed azide-alkine cicloaddition. J. Comb. Chem., 2010, 12 (1), 13-15.

[31] Rijkers, D. T. S.; van Esse, G. W.; Merkx, R.; J. Brouwer, A.; Jacobs, H. J. F.; Pieters, R. J.; Liskamp R. M. J. Efficient microwave-assisted synthesis of multivalent dendrimeric peptides using cycloaddition reaction (click) chemistry. Chem. Commun., 2005, 4581-4583.

[32] Dijkgraaf, I.; Rijnders, A.Y.; Soede, A.; Dechesne, A. C.; van Esse, G.W.; Brouwer, A.J.; Corstens, F.H.M.; Boerman, O.C.; Rijkers, D.T. S.; Liskamp, R.M.J. Synthesis of DOTAconjugated multivalent cyclic-RGD peptide dendrimers via 1,3-dipolar cycloaddition and their biological evaluation: implications for tumor targeting and tumor imaging purposes. Org. Biomol.

Chem., 2007, 5, 935-944.

[33] Perissutti, E.; Frecentese, F.; Fiorino, F.; Severino, B.; Cirillo, D.; Santagada, V.; Caliendo, G. Microwave solvent freeregioselective 1,3 dipolar cycloaddition in the synthesis of 1,4 substituted [1,2,3] triazoles as amide bond isosteres. J. Heterocycl. Chem., 2007, 44, 815-819. 
[34] Angelo, N.G.; Arora, P.S. Solution- and Solid-Phase Synthesis of triazole oligomers that display protein-like functionality. J. Org. Chem., 2007, 72, 7963-7967.

[35] van Dijk, M.; Mustafa, K.; Dechesne, A. C.; van Nostrum, C. F.; Hennink, W. E.; Rijkers D. T. S.; Liskamp R. M. J. Synthesis of peptide-based polymers by microwave-assisted cycloaddition backbone polymerization. Biomacromol., 2007, 8, 327-330.

[36] van Dijk, M.; Nollet, M. L.; Weijers, P.; Dechesne, A. C.; van Nostrum, C. F.; Hennink, W. E.; Rijkers, D. T. S.; Liskamp, R. M. Synthesis and characterization of biodegradable peptide-based polymers prepared by microwaveassisted click chemistry. Biomacromolecules, 2008, 9, 2834-2843.

[37] Géci, I.; Filichev, V. V.; Pedersen E. B. Stabilization of parallel triplexes by twisted intercalating nucleic acids (TINAs) incorporating 1,2,3-triazole units and prepared by microwaveaccelerated click chemistry. Chem. Eur. J., 2007, 13, 6379-6386.

[38] Isobe, H.; Fujino, T.; Yamazaki, N.; Guillot-Nieckowski, M.; Nakamura, E. Triazole-linked analogue of deoxyribonucleic acid (TLDNA): design, synthesis, and double-strand formation with natural DNA. Org. Lett., 2008, 10, 3729-3732.

[39] Lietard, J.; Meyer, A.; Vasseur, A.; Morvan, F. New strategies for cyclization and bicyclization of oligonucleotides by click chemistry assisted by microwaves. J. Org. Chem., 2008, 73, 191-200.

[40] Pietrzik, N.; Schmollinger, D.; Ziegler, T. Dimerization of propargyl and homopropargyl 6azido-6-deoxy-glycosides upon 1,3-dipolar cycloaddition. Belstein J. Org. Chem., 2008, 4(30) doi: 10.3762/bjoc.4.30.

[41] Ermolat'ev, D.; Dehaen, W.; Van der Eycken, E. Indirect coupling of the 2(1H)-pyrazinone scaffold with various (oligo)-saccharides via "click chemistry": En route towards glycopeptidomimetics. QSAR Comb. Sci., 2004, 23, 915-918.

[42] Bouillon, C.; Meyer, A. ; Vidal, S., Jochum, A.; Chevolot, Y.; Cloarec, J.; Praly, J.; Vasseur, J.; Morvan, F. Microwave assisted "click" chemistry for the synthesis of multiple labeledcarbohydrate oligonucleotides on solid support. J. Org. Chem., 2006, 71, 4700-4702.

[43] Morvan, F.; Meyer, A.; Jochum, A.; Sabin, C.; Chevolot, Y.; Imberty, A.; Praly, J.; Vasseur, J.; Souteyrand, E.; Vidal S. Fucosylated pentaerythrityl phosphodiester oligomers (PePOs): Automated synthesis of DNA-Based glycoclusters and binding to Pseudomonas aeruginosa lectin (PA-IIL). Bioconjug. Chem., 2007, 18, 1637-1643.

[44] Pourceau, F.; Meyer, A.; Vasseur, J. J.; Morvan, F. Combinatorial and automated synthesis of phosphodiester galactosyl cluster on solid support by click chemistry assisted by microwaves. $J$. Org. Chem., 2008, 73, 6014-6017.

[45] Vecchi, A.; Melai, B.; Marra, A.; Chiappe, C.; Dondoni, A. Microwave- Enhanced Ionothermal CuAAC for the synthesis of glycoclusters on a calix[4]arene platform. J. Org. Chem., 2008, 73, 6437-6440.

[46] Bew, S.P.; Brimage, R.A.; L'Hermit, N.; Sharma, S.V. Upper rim appended hybrid calixarenes via click chemistry. Org. Lett., 2007, 9, 3713-3716. 
[47] Joosten, J. A. F.; Tholen, N. T. H.; El Maate, F. A.; Brouwer, A. J.; van Esse, G. W.; Rijkers, D. T. S.; Liskamp, R. M. J.; Pieters R. J. High-yielding microwave- assisted synthesis of triazolelinked glycodendrimers by coppercatalyzed [3+2] cycloaddition. Eur. J. Org. Chem., 2005, 31823185 .

[48] Arnusch, C. J.; Branderhorst, H.; de Kruijff, B.; Liskamp, R. M. J.; Breukink, E.; Pieters, R. J. Enhanced membrane pore information by multimeric/oligomeric antimicrobial peptides. Biochemistry, 2007, 46, 13437-13442.

[49] Pérez-Balderas, F.; Ortega-Munoz, M.; Morales-Sanfrutos, J.; Heràndez- Mateo, F.; CalvoFlores, F. G.; Calvo-Asìn, J. A.; Isac-Garcìa, J.; Santoyo- Gonzàlez, F. Multivalent neoglycoconjugates by regiospecific cycloaddition of alkynes and azides using organic-soluble copper catalysts. Org. Lett., 2003, 5, 1951-1954.

[50] Mallard-Favier, I.; Blach, P.; Cazier, F.; Delattre, F. Efficient synthesis of a fluorescent tripod detection system for pesticides by microwave-assisted click chemistry. Carbohydr. Res., 2009, 344, 161-166.

[51] Cravotto, G.; Mendicuti, F.; Martina, K.; Tagliapietra, S.; Robaldo, B.; Barge, A. Microwavepromoted Huisgen Cycloaddition to prepare Homoand Hetero-Dimers of $\alpha-, \beta$ - and $\gamma$ - cyclodextrin. Synlett, 2008, 18, 2642-2646.

[52] Aime, S.; Gianolio, E.; Arena, F.; Barge, A.; Martina, K.; Heropoulos, G.; Cravotto, G. New cyclodextrin dimers and trimers capable of forming supramolecular adducts with shape-specific ligands. Org. Biomol. Chem., 2009, 7, 370-379.

[53] Cintas, P.; Martina, K.; Robaldo, B.; Garella, A.; Boffa, L.; Cravotto, G. Improved protocols for microwave-assisted $\mathrm{Cu}(\mathrm{I})$-Catalyzed Huisgen 1,3- dipolar cycloadditions. Collect. Czech. Chem. Commun., 2007, 72, 1014-1024.

[54] Cravotto, G.; Cintas, P. The combined use of microwaves and ultrasound: Improved tools in process chemistry and organic synthesis. Chem. Eur. J. 2007, 13 (7), 1902-1909.

[55] Munteanu, M.; Choi, S.; Ritter, H. Supramolecular structures based on dimeric combinations of cyclodextrin and adamantane via click chemistry. J. Incl. Phenom. Macrocycl. Chem., 2008, 62, 197-202.

[56] Fijten, M.W.M.; Haensch, C.; van Lankvelt, B.M.; Hoogenboom, R.; Schubert, U. S. Clickable poly(2-oxazoline)s as versatile building blocks. Macromol. Chem. Phys., 2008, 209, 1887-1895.

[57] Sommer, W. J.; Weck, M. Facile functionalization of gold nanoparticles via microwaveassisted 1,3 dipolar cycloaddition. Langmuir, 2007, 23, 11991-11995.

[58] Pradere, U.; Roy, V.; Mc Brayer, T.; Schinazi, R. F.; Agrofoglio, L. A. Preparation of ribavirin analogues by copper- and ruthenium-catalyzed azidealkyne 1,3-dipolar cycloaddition. Tetrahedron, 2008, 64, 9044-9051.

[59] Rasmussen, L. K.; Boren, B. C.; Fokin, V. V. Ruthenium-catalyzed cycloaddition of aryl azides and alkynes. Org. Lett., 2007, 9, 5337-5339. 
[60] El Akri, K.; Bougrin, K.; Balzarini, J.; Faraj, A.; Benhida, R. Efficient synthesis and in vitro cytostatic activity of 4-substituted triazolyl-nucleosides. Biorg. Med. Chem. Lett., 2007, 17, 66566659.

[61] Guezguez, R.; Bougrin, K.; El Akri, K.; Benhida, R. A highly efficient microwave-assisted solvent-free synthesis of $\alpha$ - and $\beta$-2'-Deoxy-1,2,3- Triazolyl-Nucleosides. Tetrahedron Lett., 2006, 47, 4807-4811.

[62] Ermolat'ev, D. S.; Mehta, V. P.; Van der Eycken, E. Synthesis of furo[2,3-b]pyrazine nucleoside analogues with 1,2,3-triazole linkare. QSAR Comb.Sci., 2007, 26, 1266-1273.

[63] Broggi, J.; Joubert, N.; Aucagne, V.; Berteina-Raboin, S.; Diez-Gonzales, S.; Nolan, S.; Topalis, D.; Deville-Bonne, D.; Balzarini, J.; Netyts, J.; Andrei, G.; Snoeck, R.; Agrofoglio, L. A. Alkyne-azide click chemistry mediated carbanucleosides synthesis. Nucleosides Nucleotides Nucleic Acids, 2007, 26, 1391-1394.

[64] Broggi, J.; Joubert, N.; Aucagne, V.; Zevaco, T.; Berteina-Raboin, S.; Nolan, S. P.; Agrofolio, L. A. Study of different copper(I) catalysts for the "click chemistry" approach to carbanucleosides. Nucleosides Nucleotides Nucleic Acids, 2007, 26, 779-783.

[65] Broggi, J.; Kumamoto, H.; Berteina-Raboin, S.; Nolan, S. P.; Agrofoglio, L.A. Click azidealkyne cycloaddition for the synthesis of D-(-)-1,4-disubstituted triazolo-carbanucleosides. Eur. J. Org. Chem., 2009, 1880-1888.

[66] Lucas, R.; Neto, V.; Bouazza, A. H.; Zerrouki, R.; Granet, R.; Krausz, P.; Champavier, Y. Microwave-assisted synthesis of a triazole-linked 3,-5'dithymidine using click chemistry. Tetrahedron Lett., 2008, 49, 1004-1007.

[67] Lucas, R.; Zerrouki, R.; Granet, R.; Krausz, P.; Champavier, Y. A rapid efficient microwaveassisted synthesis of a 3',5'-pentathymidine by copper(I)-catalyzed [3+2] cycloaddition. Tetrahedron, 2008, 64, 5467-5471.

[68] Kaval, N.; Ermolat'ev, D.; Appukkuttan, P.; Dehaen, W.; Kappe, O.; Van der Eycken, E. The Application of "Click Chemistry" for the Decoration of 2(1H)-Pyrazinone Scaffold: Generation of Templates. J. Comb. Chem., 2005, 7, 490-502.

[69] Beryozkina, T.; Appukkuttan, P.; Mont, N.; Van der Eycken, E. Microwave-Enhanced Synthesis of New (-)-Steganacin and (-)-Steganone Aza Analogues. Org. Lett., 2006, 8, 487-490.

[70] Mont, N.; Metha, V. P.; Appukkuttan, P.; Beryozkina, T.; Toppet, S.; Van Hecke, K.; Van Meervelt, L.; Voet, A.; DeMaeyer, M.; Van der Eycken, E. Diversity oriented microwave-assisted synthesis of (-)-Steganacin azaanalogues. J. Org. Chem., 2008, 73, 7509-7515.

[71] Appukkuttan, P.; Dehaen, W.; Fokin, V. V.; Van der Eycken, E. A Microwave-Assisted Click Chemistry Synthesis of 1,4-Disubstituted 1,2,3-Triazoles via a Copper(I)-Catalyzed ThreeComponent Reaction. Org. Lett., 2004, 6, 4223-4225.

[72] Castagnolo, D.; Dessì, F.; Radi, M.; Botta, M. Synthesis of enantiomerically pure $\alpha$-[4-(1substituted)-1,2,3-triazol-4-yl]-benzylacetamides via microwave- assisted click chemistry: towards new potential antimicrobial agents. Tetrahedron Asymmetry, 2008, 18, 1345-1350. 
[73] Sreedhar, B.; Surendra Reddy, P. Sonochemical synthesis of 1,4-disubstituted 1,2,3-triazoles in aqueous medium. Synth. Commun., 2007, 37, 805-812.

[74] Khanetskyy, B.; Dallinger, D.; Kappe, O. Combining Biginelli multicomponent and click chemistry: Generation of 6-(1,2,3-triazol-1-yl)-dihydropyrimidone libraries. J. Comb. Chem., 2004, 6; 884-892.

[75] Glasnov, T. N.; Kappe, C. O. Microwave-Assisted Click Chemistry for the Preparation of 3and 4-Triazolyl-2(1H)-quinolones as Potential Fluorescent Probes. QSAR Comb. Sci., 2007, 26, 1261-1265.

[76] Mayot, E.; Gerardin- Charbonnier, C.; Selve, C. Highly fluoroalkylated amphiphilic triazoles: Regioselective synthesis and evaluation of physicochemical properties. J. Fluor. Chem., 2005, 126, 715-720.

[77] Katritzky, A. R.; Singh, S. K. Synthesis of C-carbamoyl-1,2,3-triazoles by microwave-induced 1,3-dipolar cycloaddition of organic azides to acetylenic amides. J. Org. Chem., 2002, 67, 90779079.

[78] Katritzky, A.R.; Zhang, Y.; Singh, S.K.; Steel, P.J. 1,3-Dipolar cycloadditions of organic azides to ester or benzotriazolylcarbonyl activated acetylenic amides. Arkivoc, 2003, $X V$, 47-64.

[79] Louerat, F.; Bougrin, K.; Loupy, A.; Ochoa de Retana, A. M.; Pagalday, J.; Palacios, F. Cycloaddition reactions of azidomethyl phosphonate with acetylenes and enamines. Synthesis of triazoles. Heterocycles, 1998, 48, 161-170. 